\title{
Acceptance of Evolution Increases with Student Academic Level: A Comparison Between a Secular and a Religious College
}

\author{
Guillermo Paz-y-Miño C. • Avelina Espinosa
}

Published online: 13 October 2009

(C) Springer Science + Business Media, LLC 2009

\begin{abstract}
Acceptance of evolution among the general public, high schools, teachers, and scientists has been documented in the USA; little is known about college students' views on evolution; this population is relevant since it transits from a high-school/parent-protective environment to an independent role in societal decisions. Here we compare perspectives about evolution, creationism, and intelligent design (ID) between a secular (S) and a religious (R) college in the Northeastern USA. Interinstitutional comparisons showed that $64 \%$ (mean $\mathrm{S}+\mathrm{R}$ ) biology majors vs. $42 / 62 \%$ (S/R) nonmajors supported the exclusive teaching of evolution in science classes; $24 / 29 \%(\mathrm{~S} / \mathrm{R})$ biology majors vs. $26 / 38 \%(\mathrm{~S} / \mathrm{R})$ nonmajors perceived ID as both alternative to evolution and/or scientific theory about the origin of life; $76 \%$ (mean $\mathrm{S}+\mathrm{R}$ ) biology majors and nonmajors accepted evolutionary explanations about the origin of life; $86 \%$ (mean $\mathrm{S}+\mathrm{R}$ ) biology majors vs. $79 \%$ (mean $\mathrm{S}+\mathrm{R}$ ) nonmajors preferred science courses where human evolution is discussed; $76 \%$ (mean $\mathrm{S}+\mathrm{R}$ ) biology majors vs. 79\% (mean $\mathrm{S}+\mathrm{R}$ ) nonmajors welcomed questions about evolution in exams and/or thought that such questions should always be in exams; and $66 \%$ (mean $\mathrm{S}+\mathrm{R}$ ) biology majors vs. $46 \%$ (mean $\mathrm{S}+\mathrm{R}$ ) nonmajors admitted they accept evolution openly and/or privately. Intrainstitutional comparisons showed that overall accep-
\end{abstract}

G. Paz-y-Miño C.

Department of Biology, University of Massachusetts Dartmouth, 285 Old Westport Road,

North Dartmouth, MA 02747-2300, USA

\footnotetext{
A. Espinosa $(\bowtie)$

Department of Biology, Roger Williams University,

One Old Ferry Road,

Bristol, RI 02809, USA

e-mail: aespinosa@rwu.edu
}

tance of evolution among biologists ( $\mathrm{S}$ or $\mathrm{R}$ ) increased gradually from the freshman to the senior year, due to exposure to upper-division courses with evolutionary content. College curricular/pedagogical reform should fortify evolution literacy at all education levels, particularly among nonbiologists.

Keywords Assessment - College education . Biology major $\cdot$ Creationism · Intelligent design

\section{Introduction}

The theory of evolution proposes a naturalistic explanation about the origin, diversification, and geographic distribution of life on Earth; life's biological processes result from natural selection, mutations, gene flow, and genetic drift (Mayr 2001). Since the publication of The Origin of Species by Charles Darwin in 1859, Darwinian evolution has been scrutinized experimentally; today, Darwinism is widely accepted by the scientific community. Public acceptance of evolution, however, varies worldwide, and the USA ranks 33rd in a list of 34 other polled countries (Miller et al. 2006). Only one third of Americans accept the concept of evolution, while in Iceland, Denmark, Sweden, France, Japan, and the UK $\geq 70 \%$ of adults do (Miller et al. 2006).

Creationism and intelligent design split the public's support of evolution in today's struggle between scientific knowledge and popular belief. Creationism and its various forms, including theistic evolution, creation science, or young-earth creationism (Petto and Godfrey 2007), rely on the assumption that the universe and life were created by a Creator who guided the process. This faith-based view is not recognized by scientists as a naturalistic explanation about cosmic processes. Intelligent design (ID), a doctrine born in 
the 1980s, proposes that a Designer is responsible for the complexity in biological systems and that Darwinism cannot explain holistically the origin and evolution of the natural world, nor the intricate chemical assemblage of most organic structures (Forrest and Gross 2004, 2007; Young and Taner 2004; Miller 2007, 2008). In 2005, ID was exposed in court (Dover, Pennsylvania, Kitzmiller et al. versus Dover Area School District et al. 2005; Padian and Matzke 2009) for violating the rules of science by "invoking and permitting supernatural causation" in matters of evolution and for "failing to gain acceptance in the scientific community."

Although acceptance of evolution among the general public, high schools, teachers, and scientists has been documented (Moore and Kraemer 2005; Miller et al. 2006; Donnelly and Boone 2007; Moore 2007; Berkman et al. 2008; Coalition of Scientific Societies 2008; The Gallup Poll 2007), little is known about college students' views on evolution (Bishop and Anderson 1999; Downie and Barron 2000; Hokayem and BouJaoude 2008; Paz-y-Miño C. and Espinosa 2009). Here we report college-level perspectives about evolution, creationism, and ID at two private liberal arts institutions in Northeastern USA, the secular Roger Williams University (RWU) and the Catholic Providence College (PC). We conducted interinstitutional and intrainstitutional comparisons to assess students' views about evolution, creationism, and intelligent design in the science class; students' awareness of intelligent design; students' attitudes toward evolution; students' position about the teaching of human evolution; evolution in science exams; and students' willingness to discuss evolution. Assessing college students' perception of science is relevant since this population transits from a high-school/parent-protective environment to an independent role in societal decisions (Paz-y-Miño C. and Espinosa 2009). By understanding students' opinions concerning evolution, we aim at improving the approach with which evolution is taught and contributing to curricular/pedagogical reform for its effective teaching in college.

\section{Methods}

RWU and PC had comparable student profiles (Table 1): enrollment (RWU $n=3,806$; PC $n=3,910$ ), gender (RWU $49.9 \%$ F, 50.1\% M; PC 55.5\% F, 44.5\% M), academic level (RWU 31\% freshman, 24.9\% sophomore, $23.8 \%$ junior, $20.4 \%$ senior; PC $24.8 \%$ freshman, $24.8 \%$ sophomore, $25.5 \%$ junior, $24.9 \%$ senior), and geographic region of origin (RWU 77.3\% New England, 18.9\% East Coast, 3.8\% other; PC $67.5 \%$ New England, 25.2\% East Coast, 7.3\% other).

Four hundred and seventy-six students at RWU (biology majors $n=237$, nonmajors $n=239$ ) and 355 students at PC (biology majors $n=212$, nonmajors $n=143$ ) responded to a six-question anonymous survey to assess their views about evolution, creationism, and intelligent design. All participants signed a consent form prior the completion of the survey, which was conducted at RWU from September 1724, 2007 (weeks 4-5 of classes) and at PC from February 4-15, 2008 (weeks 4-5 of classes). The Human Subject Review Boards of both institutions approved the study. Students answered questions 1-6 in order and were instructed not to skip or go back to previous questions to fix and/or compare answers. Each question had five possible choices, which were presented randomly, and only one choice was possible per question; however, for the purpose of reporting the data in this article and matching the description of each question with the figure legends (results below), here we state the questions as follows:

Question 1: Evolution, creationism, and intelligent design in the science class. Which of the following explanations about the origin and development of life on Earth should be taught in science classes? $\mathrm{A}=$ evolution, $\mathrm{B}=$ equal time to evolution, creationism, intelligent design, $\mathrm{C}=$ do not know enough to say, $\mathrm{D}=$ creationism, $\mathrm{E}=$ intelligent design.

Question 2: Intelligent Design (ID). Which of the following statements is consistent with ID? A = no opinion, $\mathrm{B}=\mathrm{ID}$ is religious doctrine consistent with creationism, $\mathrm{C}=\mathrm{ID}$ is a scientific alternative to evolution and of equal scientific validity among scientists, $\mathrm{D}=\mathrm{ID}$ is a scientific theory about the origin and evolution of life on Earth, E = ID is not scientific but has been proposed to counter evolution based on false scientific claims.

Question 3: Evolution and your reaction to it. Which of the following statements fits best your position concerning evolution? A = hearing about evolution makes me appreciate the factual explanation about the origin of life on Earth and its place in the universe, $\mathrm{B}=$ hearing about evolution makes no difference to me because evolution and creationism are in harmony, $\mathrm{C}=$ do not know enough to say, $\mathrm{D}$ = hearing about evolution makes me uncomfortable because it is in conflict with my faith, $\mathrm{E}=$ hearing about evolution makes me realize how wrong scientists are concerning explanations about the origin of life on Earth and the universe.

Question 4: Your position about the teaching of human evolution. With which of the following statements do you agree? A = I prefer science courses where evolution is discussed comprehensively and humans are part of it, B = I 
prefer science courses where plant and animal evolution is discussed but not human evolution, $\mathrm{C}=$ do not know enough to say, $\mathrm{D}=\mathrm{I}$ prefer science courses where the topic evolution is never addressed, $\mathrm{E}=\mathrm{I}$ avoid science courses with evolutionary content.

Question 5: Evolution in science exams. Which of the following statements fits best your position concerning science exams? A = I have no problem answering questions concerning evolution, $\mathrm{B}=$ science exams should always include some questions concerning evolution, $\mathrm{C}=$ do not know enough to say, $\mathrm{D}=\mathrm{I}$ prefer to not answer questions concerning evolution, $\mathrm{E}=\mathrm{I}$ never answer questions concerning evolution.

Question 6: Your willingness to discuss evolution. Select the statement that describes you best: $\mathrm{A}=\mathrm{I}$ accept evolution and express it openly regardless of others' opinions, $\mathrm{B}=$ no opinion, $\mathrm{C}=\mathrm{I}$ accept evolution but do not discuss it openly to avoid conflicts with friends and family, D = I believe in creationism and express it openly regardless of others' opinions, $\mathrm{E}=\mathrm{I}$ believe in creationism but do not discuss it openly to avoid conflicts with friends and family.

\section{Statistical Analyses}

Interinstitutional Comparisons We conducted three types of comparisons between institutions (RWU versus PC), biology majors, nonmajors, or academic level of biology majors (one comparison each: freshman, sophomore, junior, or senior), and analyzed separately the data generated in each of the six questions (i.e., questions 1, 2, 3, 4, 5, or 6; choices A, B, C, D, or E). Data from each question were organized in $2 \times 5$ contingency tables, for example, $R W U$ biology majors, $P C$ biology majors $\times A, B$, $C, D, E$ (Chi-square tests, null hypotheses rejected at $P \leq 0.05)$. Because questions $1,3,4,5$, or 6 had none or very few responders $(<5 \%$; note that Chi-square analyses are inaccurate when over $20 \%$ of the expected values are less than 5; Sieger and Castellan 1988) in one, two, or three of the choices ( $\mathrm{E}$ or $\mathrm{DE}$ or $\mathrm{CDE}$ ), we eliminated such choices and created $2 \times 4,2 \times 3$, and $2 \times 2$ contingency tables for the remaining groups in each question, respectively (Chi-square tests, null hypotheses rejected at $P \leq 0.05$ ). All pairwise comparisons between relevant groups were analyzed with sign test two-tail, null hypotheses rejected at $P \leq 0.05$.

Intrainstitutional Comparisons Because at both RWU and PC exposure to evolutionary theory differs between biology majors and nonmajors (see notes in Table 1), as well as increases with academic level among biology majors (from basic to advance biology courses), while nonmajors attend fewer courses with evolutionary content, we conducted two types of comparisons within institutions (RWU or PC), biology majors versus nonmajors or responses of biology majors to questions 1-6 as function of academic level (i.e., freshman, sophomore, junior, senior), and analyzed separately the data generated in each of the six questions (above). Data from the biology major versus nonmajor comparisons were organized in $2 \times 5$ contingency tables, for example, $R W U$ biology majors, $R W U$ nonmajors $\times A, B, C$, $D, E$ (Chi-square tests, null hypotheses rejected at $P \leq 0.05$ ). Because questions $1,3,4,5$, or 6 for the comparison of biology major versus nonmajor had none or very few responders $(<5 \%)$ in one, two, or three of the choices (E or DE or CDE), we eliminated such choices and created $2 \times 4$, $2 \times 3$, and $2 \times 2$ contingency tables for the remaining groups in each question, respectively (Chi-square tests, null hypotheses rejected at $P \leq 0.05$ ). All pairwise comparisons between relevant groups were analyzed with sign test twotail, null hypotheses rejected at $P \leq 0.05$. Data from the responses of biology majors as function of academic level were organized in $4 \times 5$ contingency tables, for example, $R W U$ freshman, $R W U$ sophomore, $R W U$ junior, $R W U$ senior $\times A, B, C, D, E$ (Chi-square tests, null hypotheses rejected at $P \leq 0.05$ ). Because questions $1,3,4,5$, or 6 for the comparison of responses of biology majors as function of academic level had none or very few responders $(<5 \%)$ in one, two, or three of the choices (E or DE or CDE), we eliminated such choices and created $4 \times 4,4 \times 3$, and $4 \times 2$ contingency tables, respectively (Chi-square tests, null hypotheses rejected at $P \leq 0.05)$. Linear regression was used to analyze students' responses to the remaining choices (e.g., $A, B$ ) in each question as function of year/academic level: 1/freshman, 2/sophomore, 3/junior, 4/senior (null hypotheses rejected at $P \leq 0.05$ ).

\section{Results}

Interinstitutional Comparisons

Evolution, Creationism, and Intelligent Design in the Science Class Biology majors at RWU and PC had similar views about the teaching of evolution (Fig. 1a, Chi-square= 1.077, $d f=2, P=0.58): 64 \%$ of the combined student responders (mean RWU $+\mathrm{PC}$ ) considered that evolution should be taught in science classes as an explanation about the origin and development of life on Earth; 29\% favored equal time to evolution, creationism, and intelligent design, and $6 \%$ did not know enough to say. The nonmajors' views differed between institutions (Fig. 1b, Chi-square=9.0, $d f=2$, 


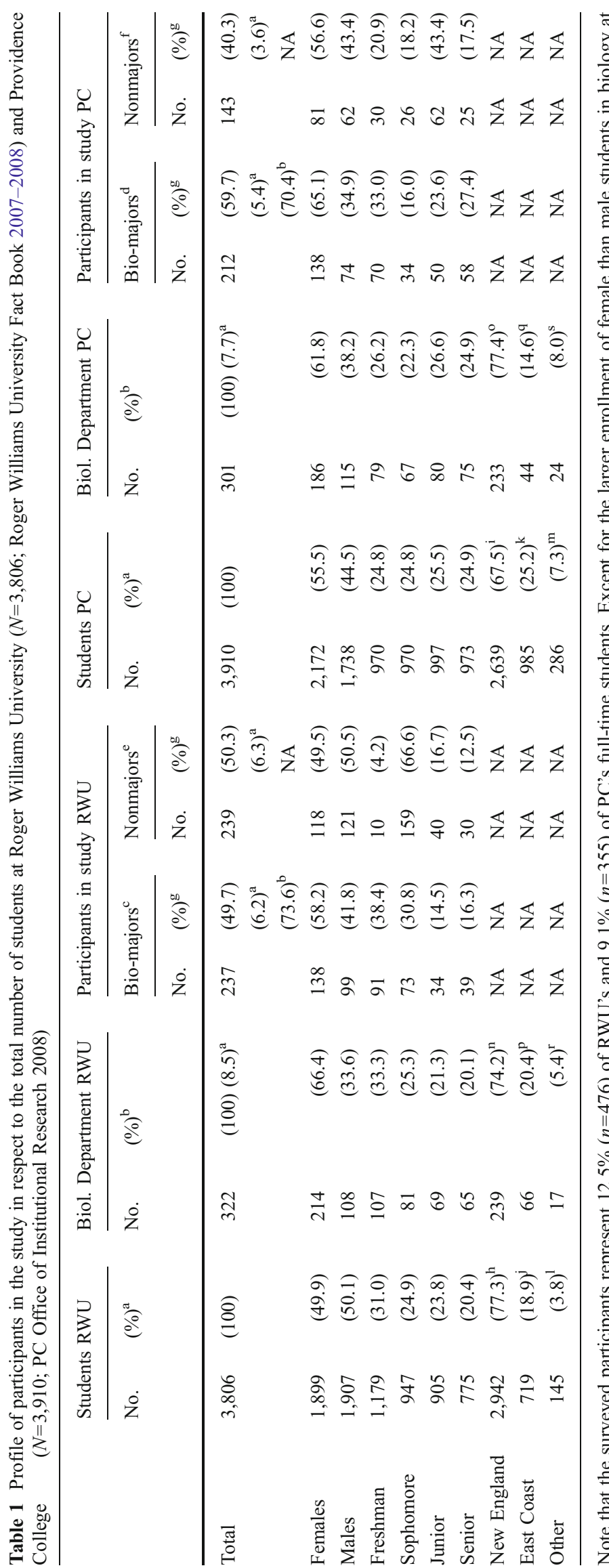

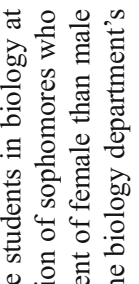

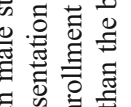

을

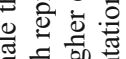

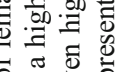

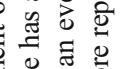

竞范

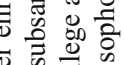

한

율 을

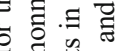

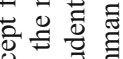

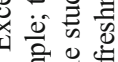

初苛

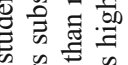

की

产递兽

is 苛苛

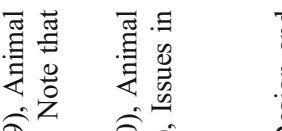

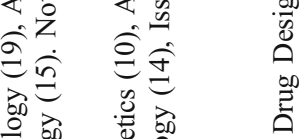

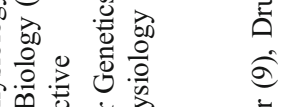

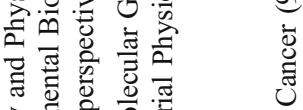

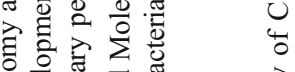

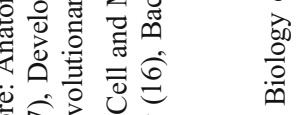

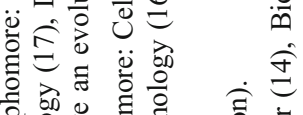

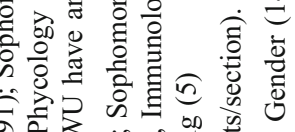

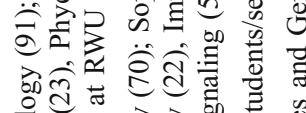

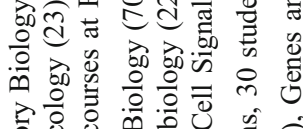

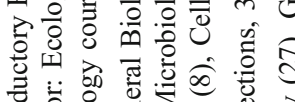

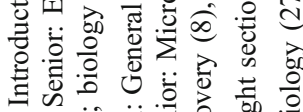

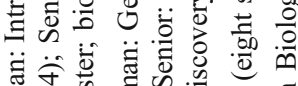

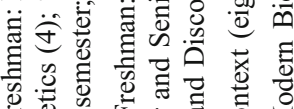

जू.

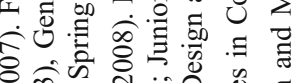

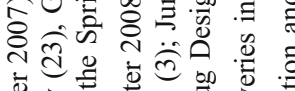

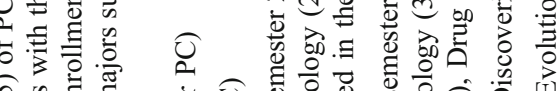

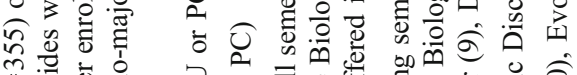

II.

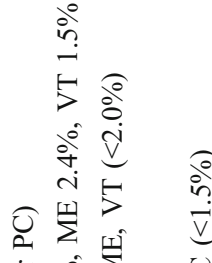

2

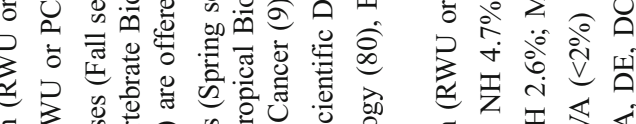

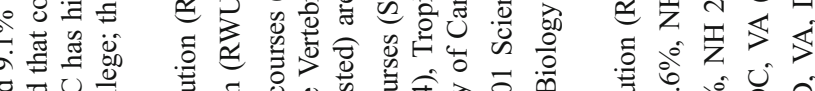

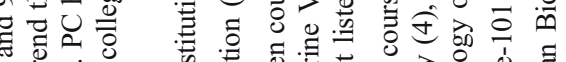

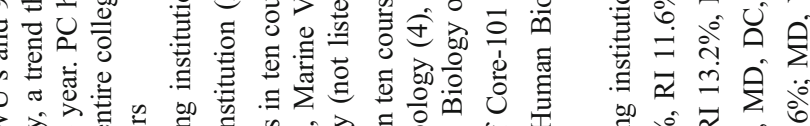

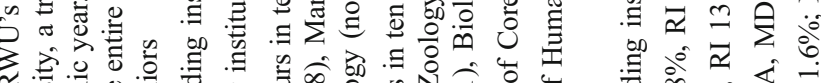

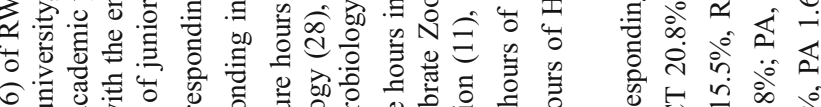

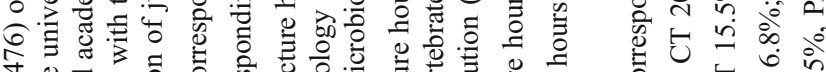

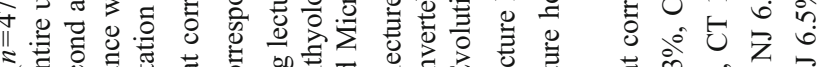

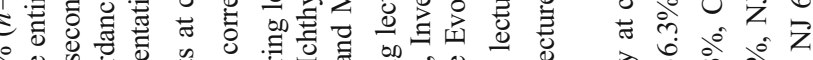

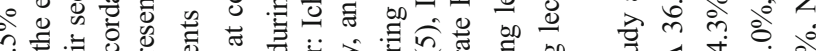

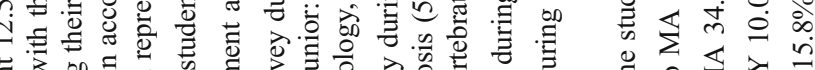

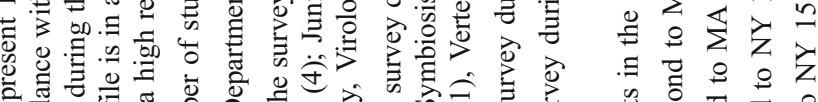

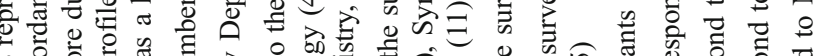

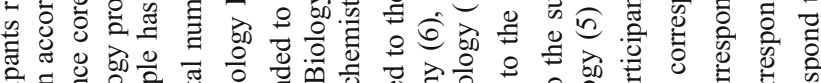

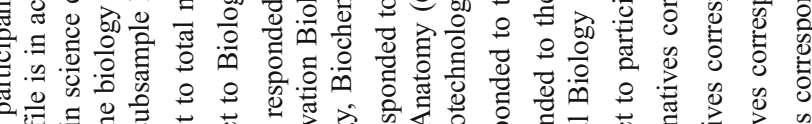

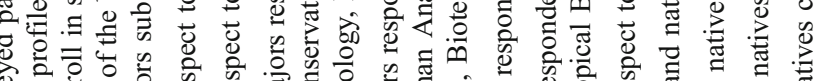

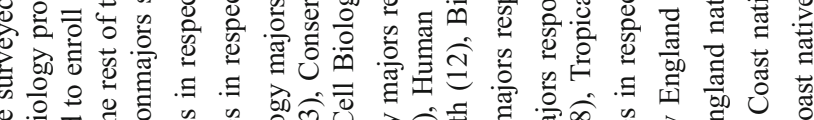

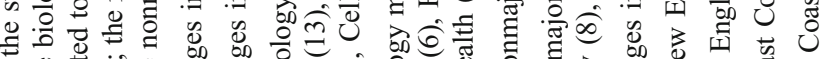

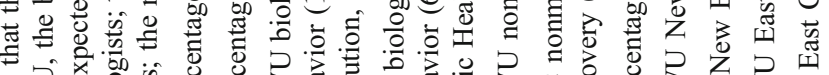

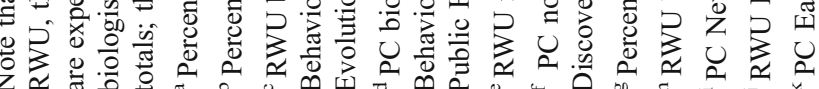


$P=0.01$ ): $42 \%$ of RWU versus $62 \%$ of PC responders thought that evolution should be taught in science classes (sign test two-tail pairwise comparison $P \leq 0.05$ ); $45 \%$ of RWU versus $30 \%$ of PC students favored equal time to evolution, creationism, and intelligent design, and $12 \%$ of RWU versus $7 \%$ of PC students did not know enough to say. Figure 1c-f summarizes the views of biology majors (RWU versus PC) according to their academic level: $51 \%$ of the combined freshman responders, 62\% sophomores, $72 \%$ juniors, and $81 \%$ seniors considered that evolution should be taught in science classes. Support to equal time to evolution, creationism, and intelligent design was particularly high among freshman (41\%); less than one third of sophomore, junior, or senior students supported this view.

Intelligent Design Biology majors at RWU and PC differed in their views about ID (Fig. 2a, Chi-square $=20.943, d f=4$, $P \leq 0.001$ ): $47 \%$ of RWU versus $17 \%$ of PC responders had no opinion about ID (sign test two-tail pairwise comparison $P \leq 0.05$ ), $16 \%$ of RWU versus $32 \%$ of PC responders thought ID is a religious doctrine consistent with creationism (sign test two-tail pairwise comparison $P \leq 0.05$ ), while $9 \%$ of the combined student responders (mean RWU + PC) considered ID to be a scientific alternative to evolution and of equal scientific validity among scientists, 17\% thought ID is a scientific theory about the origin and evolution of life on Earth, and 17\% considered ID not scientific but proposed to counter evolution based on false scientific claims. The nonmajors' views about ID differed between institutions (Fig. 2b, Chi-square $=10.946, d f=4, P=0.02$ ): $49 \%$ of RWU versus $27 \%$ of PC responders had no opinion about ID (sign test two-tail pairwise comparison $P \leq 0.05$ ), $18 \%$ of the combined student responders (mean RWU + PC) thought ID is religious doctrine, $10 \%$ considered ID to be a scientific alternative to evolution, 22\% thought ID is a scientific theory, and $11 \%$ considered ID not scientific and proposed to counter evolution. Figure $2 \mathrm{c}-\mathrm{f}$ summarizes the views of biology majors (RWU versus PC) according to their academic level: more RWU than PC freshmen $(57 \%$ vs. $25 \%$ ), sophomores (39\% vs. $8 \%$ ), juniors (36\% vs. $17 \%$ ), or seniors ( $48 \%$ vs. $12 \%$ ) had no opinion about ID; more PC than RWU sophomores (44\% vs. 20\%), juniors (36\% vs. $15 \%$ ), or seniors (34\% vs. $16 \%$ ) thought ID is a religious doctrine; and more PC than RWU freshmen $(20 \%$ vs. 3\%) considered ID a scientific alternative to evolution (all pairwise comparisons sign test two-tail $P \leq 0.05$ ).

Evolution and Students' Reaction to It Biology majors at RWU and PC coincided in their position about evolution (Fig. 3a, Chi-square $=1.001, d f=1, P=0.31$ ): $76 \%$ of the combined student responders (mean RWU + PC) thought that hearing about evolution makes them appreciate the factual explanation about the origin of life on Earth and its place in 
Fig. 1 Percentage of RWU (black bars) versus PC (white bars) students who consider one of the following explanations about the origin and development of life on Earth should be taught in science classes: $A=$ evolution, $B=$ equal time to evolution, creationism, intelligent design, $C=$ do not know enough to say. Comparisons between institutions: a biology majors (RWU=237, PC=212), Chi-square $=1.077, d f=2$, $P=0.58$. b Nonmajors (RWU = 239, $\mathrm{PC}=143)$, Chi-square $=9.0$, $d f=2, P=0.01 ;$ asterisk indicates sign test two-tail pairwise comparison $P \leq 0.05$. c Biology freshman (RWU $n=93, \mathrm{PC}$ $n=70$ ), Chi-square $=0.307$, $d f=2, P=0.85$. d Biology sophomore (RWU $n=74, \mathrm{PC}$ $n=34)$, Chi-square $=1.459$, $d f=2, P=0.48$. e Biology junior (RWU $n=33$, PC $n=50$ ), Chisquare $=8.282, d f=2, P=0.016$. f Biology senior (RWU $n=37$, PC $n=58)$, Chi-square $=0.260$, $d f=2, P=0.87$

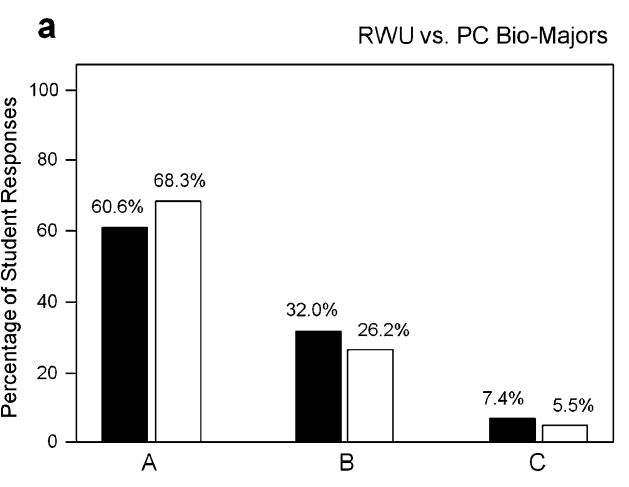

b

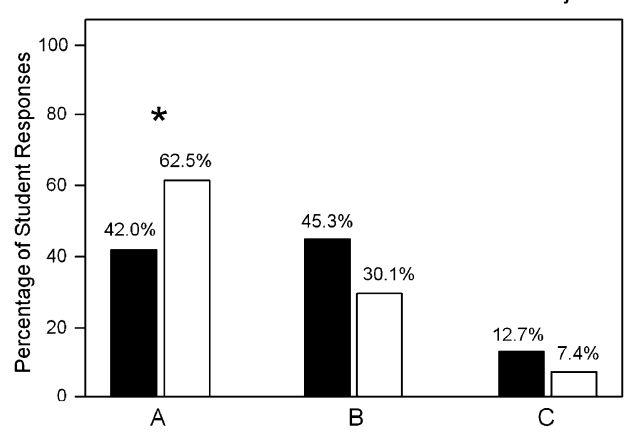

$$
\text { C }
$$

RWU vs. PC Bio-Freshman
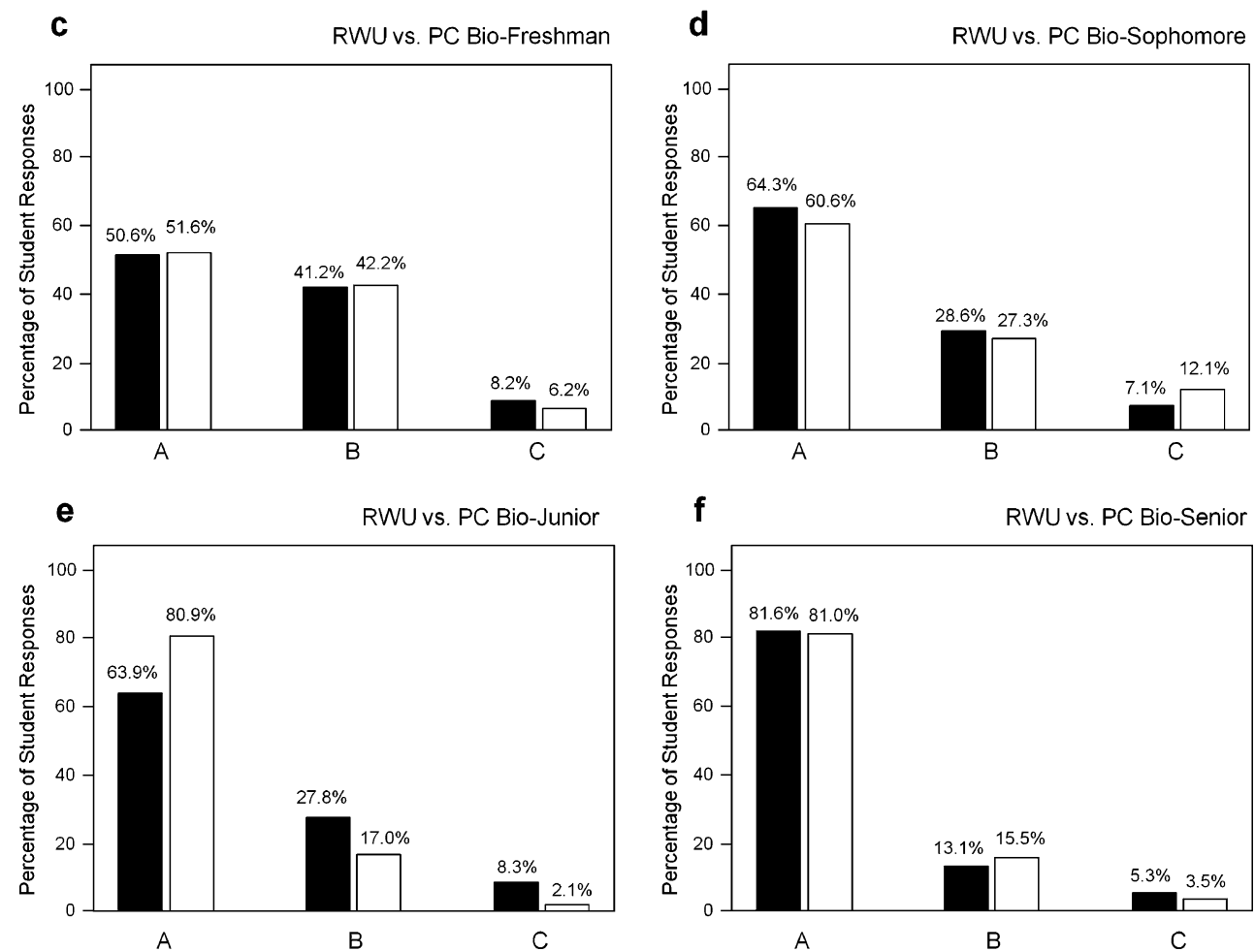
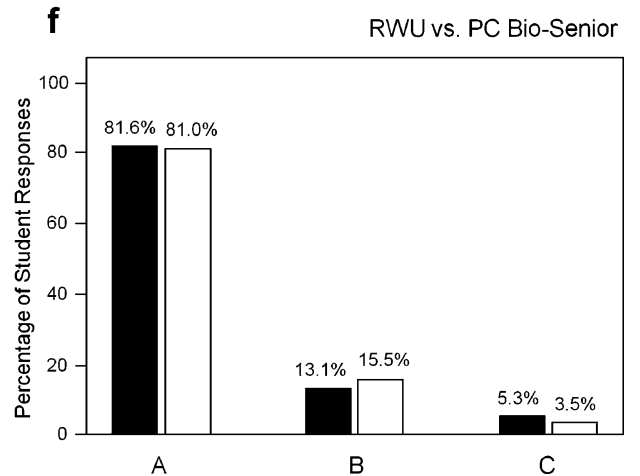

the universe, while $23 \%$ considered that hearing about evolution makes no difference because evolution and creationism are in harmony. The nonmajors' views were similar between both institutions (Fig. 3b, Chi-square $=0.027, d f=1$, $P=0.86$ ): $76 \%$ of the combined student responders expressed appreciation for the factual explanations about the origin of life on Earth, and 24\% considered that evolution and creationism are in harmony. Figure $3 \mathrm{c}-\mathrm{f}$ summarizes the views of biology majors (RWU versus PC) according to their academic level: $68 \%$ of the combined freshman responders, $75 \%$ sophomores, $82 \%$ juniors, and $86 \%$ seniors favored the factual explanations about the origin of life on Earth. About one third of the combined freshman responders perceived harmony between evolution and creationism; less than one quarter of sophomore, junior, or senior agreed with this view.

Students' Position About the Teaching of Human Evolution Biology majors at RWU and PC agreed on their views about the teaching of human evolution (Fig. 4a, Chi-square= 1.543, $d f=2, P=0.46): 86 \%$ of the combined student responders (mean RWU + PC) preferred science courses where evolution is discussed comprehensively and humans are part of it; $8 \%$ preferred evolution discussions about plants and animals but not humans, and 6\% did not know enough to say. The nonmajors' views were similar between both institutions (Fig. 4b, Chi-square $=3.723, d f=2, P=$ 0.15): $79 \%$ of the combined student responders welcomed the teaching of human evolution; $8 \%$ preferred evolution discussions about plants and animals but not humans, and $14 \%$ did not know enough to say. Figure 4c-f summarizes the views of biology majors (RWU versus PC) according to their academic level: $88 \%$ of the combined freshman responders, 90\% sophomores, 95\% juniors, and 97\% seniors favored the teaching of human evolution in science courses. About one tenth or less of the combined freshman, sophomore, junior, or senior responders preferred evolution 
Fig. 2 Percentage of RWU (black bars) versus PC (white bars) students who consider one of the following statements is consistent with ID: $A=$ no opinion, $B=\mathrm{ID}$ is religious doctrine consistent with creationism, $C=$ ID is a scientific alternative to evolution and of equal scientific validity among scientists, $D=$ ID is a scientific theory about the origin and evolution of life on Earth, $E=$ ID is not scientific but has been proposed to counter evolution based on false scientific claims. Comparisons between institutions: a biology majors (RWU $n=237$, PC $n=212$ ), Chi-square $=20.943$, $d f=4, P \leq 0.001$. b Nonmajors (RWU $n=239$, PC $n=143$ ), Chi-square $=10.946, d f=4$, $P=0.02$. c Biology freshman (RWU $n=93$, PC $n=70$ ), Chi-square $=27.152, d f=4$, $P \leq 0.001$. d Biology sophomore (RWU $n=74, \mathrm{PC} n=34$ ), Chi-square $=35.625, d f=4$, $P \leq 0.001$. e Biology junior (RWU $n=33, \mathrm{PC} n=50$ ), Chi-square $=16.577, d f=4$, $P=0.002$. f Biology senior (RWU $n=37, \mathrm{PC} n=58$ ), Chi-square $=34.145, d f=4$, $P \leq 0.001$. Asterisks indicate sign test two-tail pairwise comparisons $P \leq 0.05$

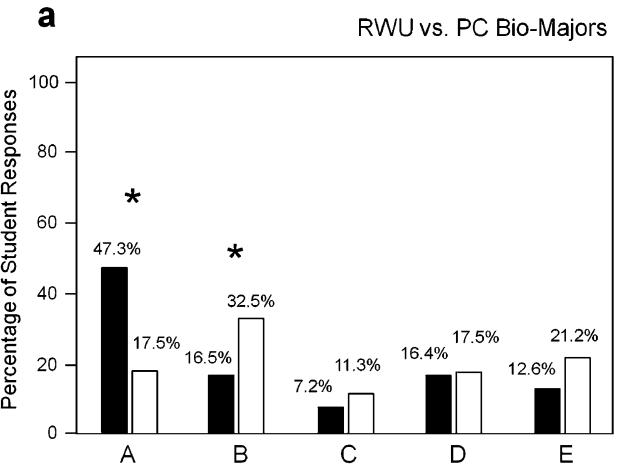

b
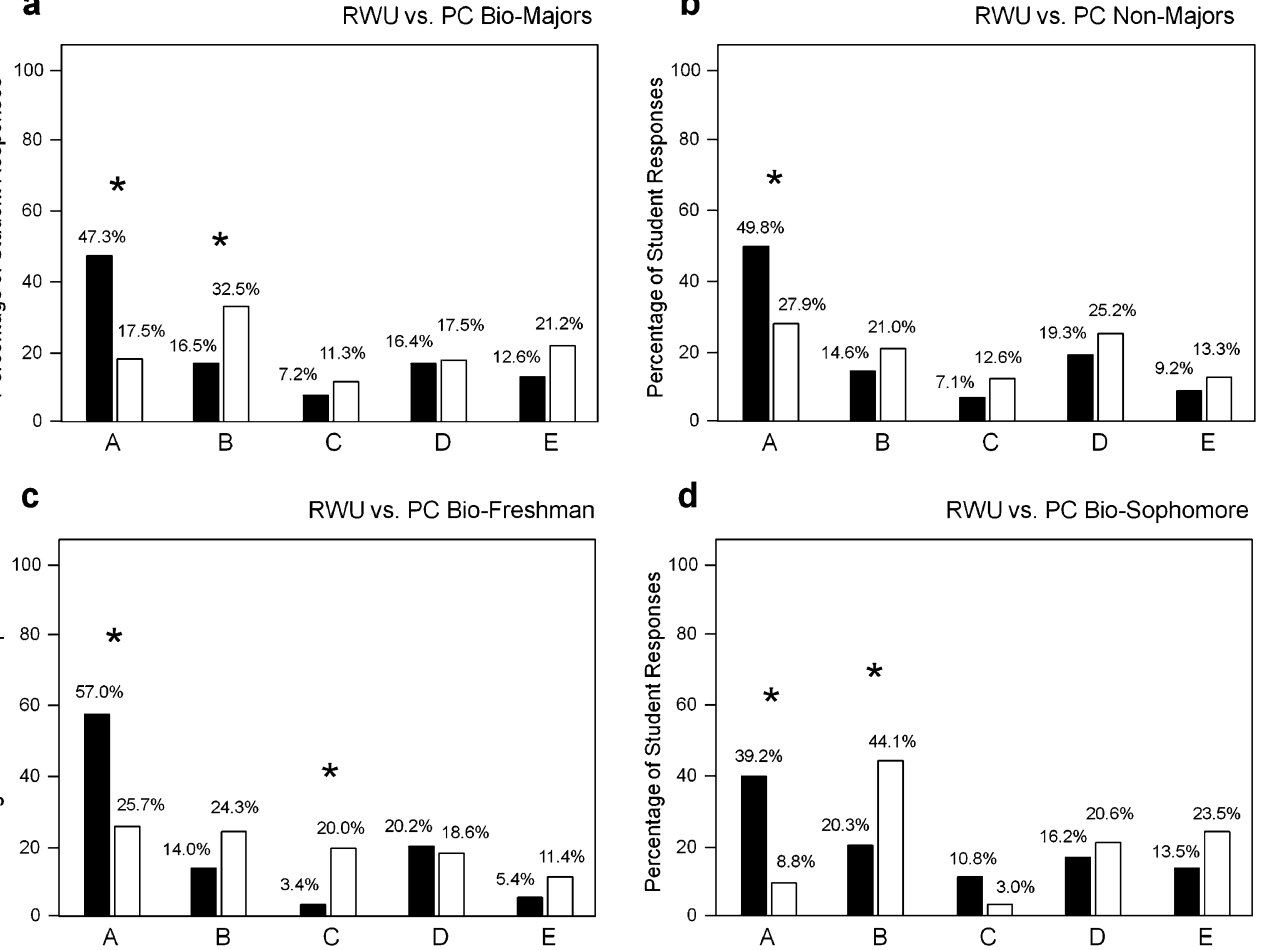

d
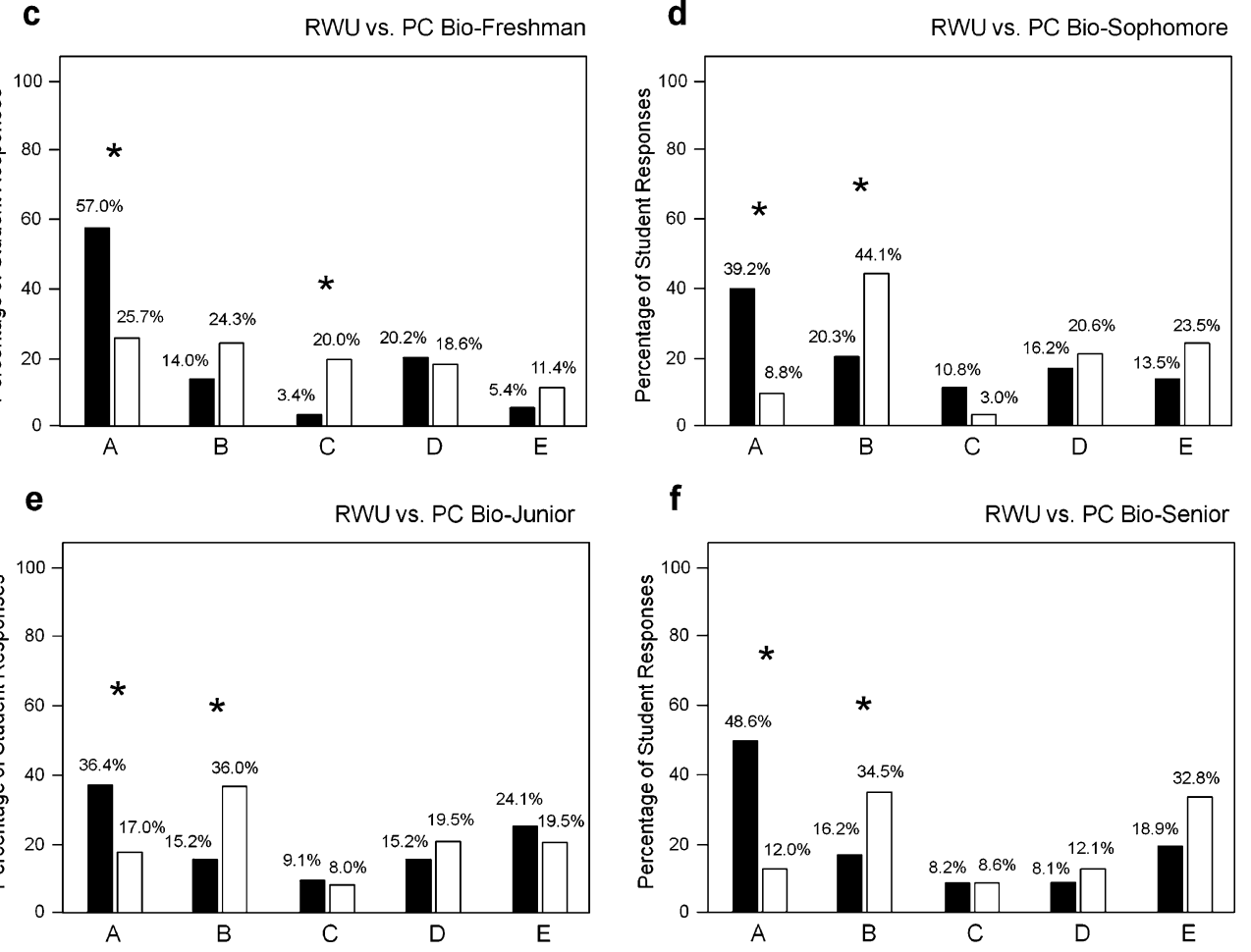

discussions about plants and animals but not humans; note that more RWU sophomores than their counterparts at PC agreed with this view (sign test two-tail pairwise comparison $P \leq 0.05$ ).

Evolution in Science Exams Biology majors at RWU and PC shared opinions about the inclusion of evolution in science exams (Fig. 5a, Chi-square $=1.058, d f=2, P=0.58$ ): $76 \%$ of the combined student responders (mean RWU + PC) had no problem with answering questions concerning evolution in exams; 19\% considered that exams should always include some questions concerning evolution, and $5 \%$ did not know enough to say. The nonmajors' views were similar between both institutions (Fig. 5b, Chi-square $=$ 1.649, $d f=2, P=0.43): 79 \%$ of the combined student responders welcomed questions concerning evolution in exams; $12 \%$ thought that exams should always include some questions concerning evolution, and 9\% did not know enough to say. Figure $5 \mathrm{c}-\mathrm{f}$ summarizes the views of biology majors (RWU versus PC) according to their academic level: $83 \%$ of the combined freshman responders, $76 \%$ of sophomores, $78 \%$ of juniors, and $80 \%$ of seniors favored the inclusion of evolution in science exams. About one fifth or less of the combined freshman, sophomore, junior, or senior responders considered that exams should always include some questions concerning evolution.

Students' Willingness to Discuss Evolution Biology majors at RWU and PC showed similar willingness to offer opinions about evolution (Fig. 6a, Chi-square $=7.696$, $d f=4, P=0.1): 52 \%$ of the combined student responders (mean RWU + PC) indicated that they accept evolution and express it openly regardless of others' opinions; $26 \%$ preferred not to comment on this issue, and $14 \%$ admitted to accept evolution but not discuss it openly to avoid conflicts with friends and family; the remaining $8 \%$ either 

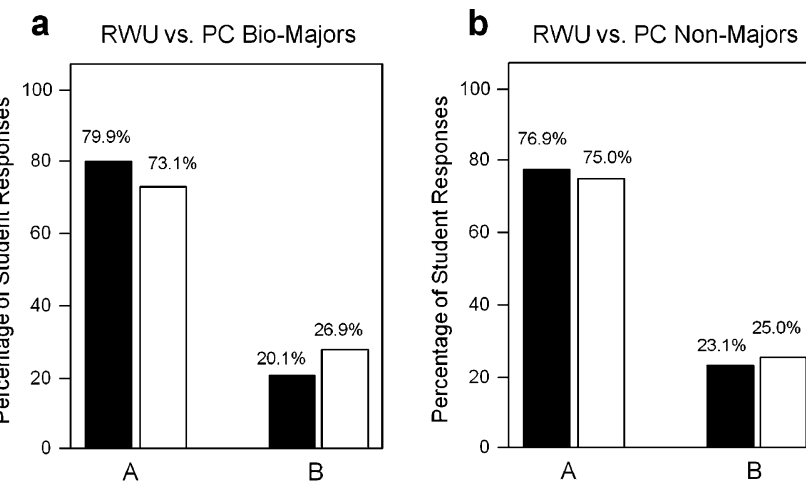

C

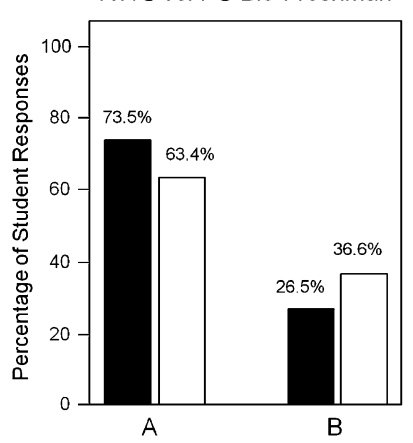

e RWU vs. PC Bio-Junior

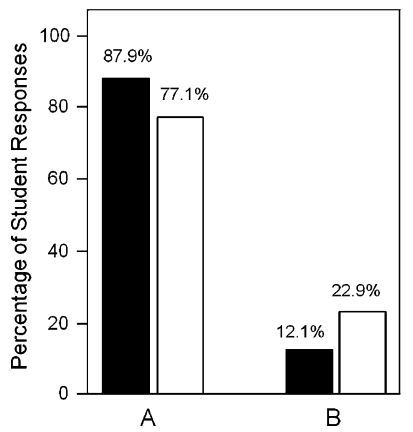

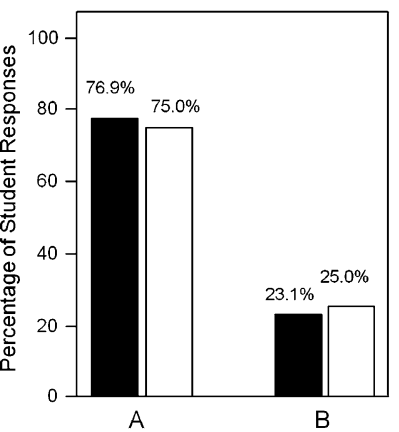

d RWU vs. PC Bio-Sophomore

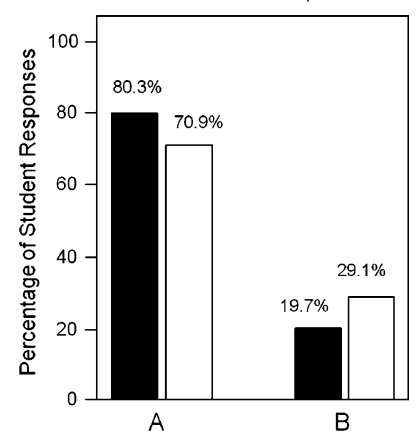

f RWU vs. PC Bio-Senior

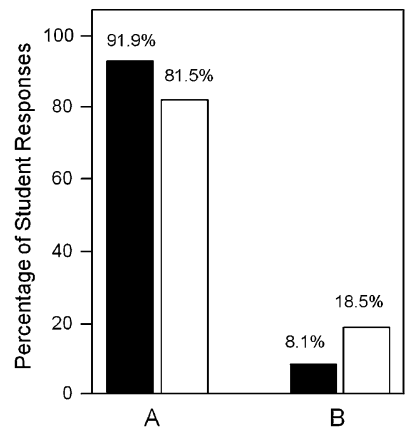

Fig. 3 Percentage of RWU (black bars) versus PC (white bars) students who think one of the following statements fits best their position concerning evolution: $A=$ hearing about evolution makes me appreciate the factual explanation about the origin of life on Earth and its place in the universe, $B=$ hearing about evolution makes no difference to me because evolution and creationism are in harmony. Comparisons between institutions: a biology majors (RWU $n=237$, PC $n=212$ ), Chi-square $=1.001, d f=1, P=0.317$. b Nonmajors (RWU $n=239$, PC $n=143$ ), Chi-square $=0.027, d f=1, P=0.86$. c Biology freshman (RWU $n=93, \mathrm{PC} n=70)$, Chi-square $=2.317, d f=1, P=0.12$. d Biology sophomore (RWU $n=74$, PC $n=34$ ), Chi-square $=1.173$, $d f=1, P=0.18$. e Biology junior (RWU $n=33$, PC $n=50)$, Chi-square $=$ 3.463, $d f=1, P=0.06$. f Biology senior (RWU $n=37$, PC $n=58$ ), Chisquare $=3.581, d f=1, P=0.058$. Combined student responders (mean of RWU + PC) for $A$ vs. $B$ differ in all figures, sign test two-tail $P \leq 0.05$

believe in creationism and express it openly regardless of others' opinions or believe in creationism but do not discuss it openly to avoid conflicts with friends and family. The nonmajors' willingness to discuss evolution was

similar between both institutions (Fig. 6b, Chi-square= 5.315, $d f=4, P=0.25): 33 \%$ of the combined student responders indicated that they accept evolution and express it openly; $42 \%$ preferred not to comment on this issue, and $13 \%$ admitted that they accept evolution but do not discuss it openly; the remaining $12 \%$ either believe in creationism and express it openly or do not discuss it openly. Figure $6 \mathrm{c}-\mathrm{f}$ summarizes the views of biology majors (RWU versus PC) according to their academic level: $46 \%$ of the combined freshman responders, $52 \%$ sophomores, $60 \%$ juniors, and $67 \%$ seniors accept evolution and express it openly. About one third or less of the combined freshman, sophomore, junior, or senior responders did not comment on this issue, and one fifth or less of them admitted to accept evolution but not discuss it openly; note that more PC freshman than their counterparts at RWU believe in creationism but do not discuss it openly (sign test two-tail pairwise comparison $P \leq 0.05$ ).

Intrainstitutional Comparisons

Evolution, Creationism, and Intelligent Design in the Science Class Biology majors versus nonmajors' views about the teaching of evolution differ at RWU (Fig. 7a, Chi-square $=7.5, d f=2, P=0.02$ ) but not at PC (Fig. 7b, Chi-square $=0.553, d f=2, P=0.75$ ). At RWU, $60 \%$ of biology majors versus $42 \%$ of nonmajors considered that evolution should be taught in science classes as an explanation about the origin and development of life on Earth; $32 \%$ of biology majors versus $45 \%$ of nonmajors favored equal time to evolution, creationism, and intelligent design, and $7 \%$ of biology majors versus $12 \%$ of nonmajors did not know enough to say. At PC, $65 \%$ of the combined student responders (mean biology majors + nonmajors) supported the teaching of evolution; $28 \%$ favored equal time to evolution, creationism, and intelligent design, and $6 \%$ did not know enough to say. Agreement with the teaching of evolution in science classes increases according to biology majors' academic level at both RWU (Fig. 7c, Chi-square $=22.542, d f=6, P \leq 0.001)$ and PC (Fig. $7 \mathrm{~d}$, Chisquare $=35.809, d f=6, P \leq 0.001$ ), from $50 \%$ among freshman to $81 \%$ among seniors (both institutions, RWU: $r=$ 0.94, $P=0.059$; PC: $r=0.94, P=0.054)$. Although $42 \%$ of freshman agreed with equal time in the science class to evolution, creationism, and intelligent design, this opinion dropped below $15 \%$ among seniors (both institutions, RWU: $r=0.95, P=0.044$; PC: $r=0.94, P=0.052$ ).

Intelligent Design Biology majors versus nonmajors did not differ in their views about ID at either RWU (Fig. 8a, Chisquare $=1.202, d f=4, P=0.87$ ) or PC (Fig. $8 \mathrm{~b}$, Chi-square $=$ $8.024, d f=4, P=0.09)$. At RWU, $48 \%$ of the combined student responders (mean biology majors + nonmajors) had 

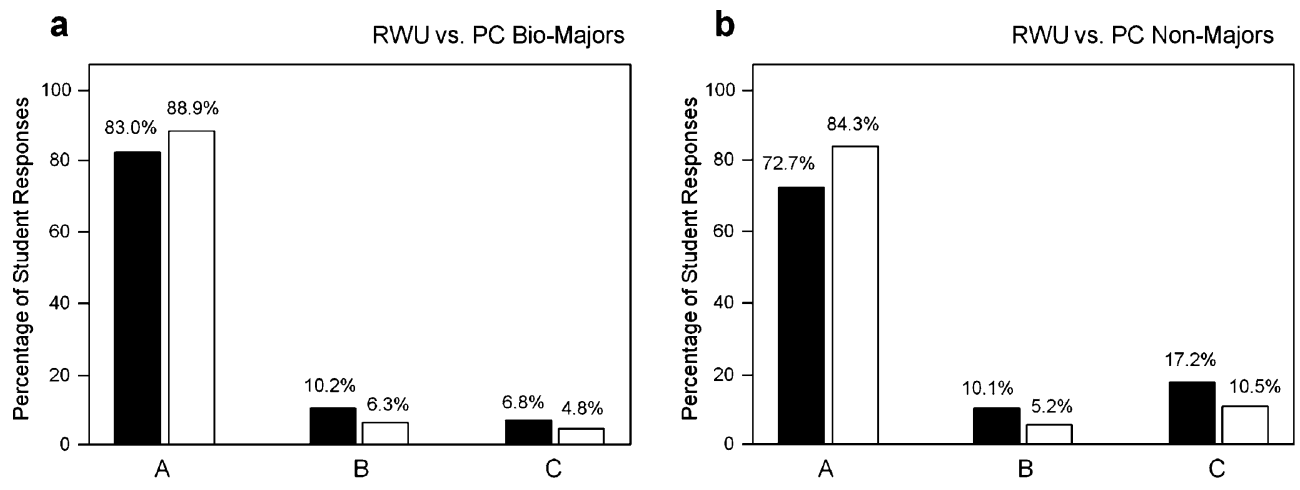

C RWU vs. PC Bio-Freshman

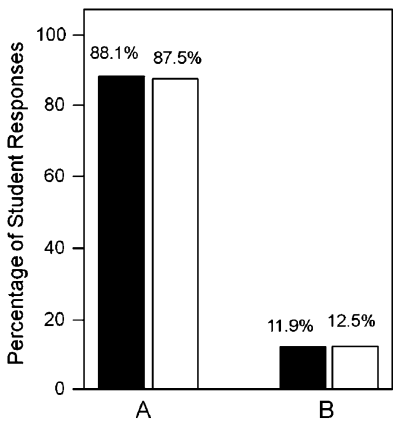

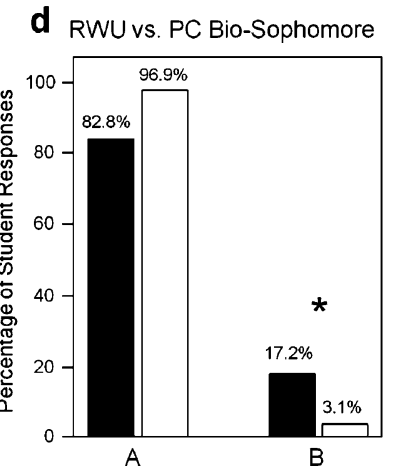

e RWUvs. PC Bio-Junior

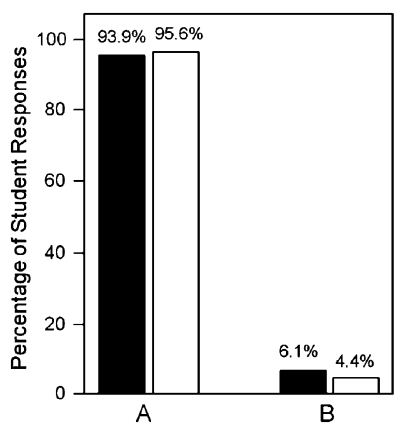

Fig. 4 Percentage of RWU (black bars) versus PC (white bars) students who agree with one of the following statements concerning their own education: $A=\mathrm{I}$ prefer science courses where evolution is discussed comprehensively and humans are part of it, $B=\mathrm{I}$ prefer science courses where plant and animal evolution is discussed but not human evolution, $C=$ do not know enough to say. Comparisons between institutions: a biology majors (RWU $n=237$, PC $n=212$ ), Chi-square $=1.543, d f=2, P=0.46$. b Nonmajors (RWU $n=239, \mathrm{PC}$ $n=143$ ), Chi-square $=3.723, d f=2, P=0.15$. c Biology freshman

no opinion about ID; $16 \%$ thought ID is a religious doctrine consistent with creationism; $7 \%$ considered ID to be a scientific alternative to evolution and of equal scientific validity among scientists; $18 \%$ thought ID is a scientific theory about the origin and evolution of life on Earth, and $11 \%$ considered ID not scientific but proposed to counter evolution based on false scientific claims. At PC, $23 \%$ of the combined student responders had no opinion about ID; $27 \%$ thought ID is religious doctrine; $12 \%$ considered ID to be a scientific alternative to evolution; $21 \%$ thought ID is a scientific theory, and $17 \%$ considered ID not scientific and proposed to counter evolution. Except for the high proportion (mean 45\%) of RWU biology majors who had no opinion about ID (Fig. 8c, choice A) and one third (mean $34 \%$ ) of PC biology majors who perceived ID as religious doctrine consistent with creationism (Fig. 8d, choice B), views about ID varied with no definite trend at either RWU or PC.

Evolution and Students' Reaction to It Biology majors versus nonmajors did not coincide in their position about f RWU vs. PC Bio-Senior

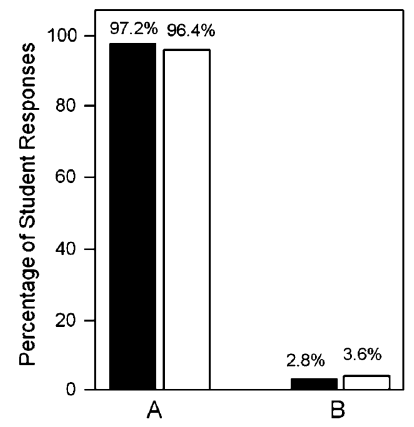

(RWU $n=93$, PC $n=70$ ), Chi-square $=3.953, d f=1, P=1.0$. d Biology sophomore (RWU $n=74$, PC $n=34$ ), Chi-square $=9.389, d f=1, P=$ 0.002 ; asterisk indicates sign test two-tail pairwise comparison $P \leq$ 0.05 . e Biology junior (RWU $n=33$, PC $n=50$ ), Chi-square $=0.105$, $d f=1, P=0.74$. f Biology senior (RWU $n=37, \mathrm{PC} n=58$ ), Chi-square= 2.082, $d f=1, P=1.0$. Combined freshman, sophomore, junior, and senior responders (mean of RWU + PC) for $A$ vs. $B$ differ in $\mathbf{c}$ to f, sign test two-tail $P \leq 0.05$

evolution at RWU (Fig. 9a, Chi-square $=8.651, d f=3, P=$ 0.03 ) but they did at PC (Fig. 9b, Chi-square $=0.026, d f=1$, $P=0.87$ ). At RWU, $71 \%$ biology majors versus $57 \%$ nonmajors thought that hearing about evolution makes them appreciate the factual explanation about the origin of life on Earth and its place in the universe; $18 \%$ of the combined student responders (mean biology majors + nonmajors) considered that hearing about evolution makes no difference because evolution and creationism are in harmony; $7 \%$ biology majors versus $18 \%$ nonmajors did not know enough to say (sign test two-tail pairwise comparison $P \leq 0.05$ ), and $5 \%$ of the combined student responders admitted that hearing about evolution makes them uncomfortable because it is in conflict with their faith. At PC, $74 \%$ of the combined student responders agreed that hearing about evolution makes them appreciate the factual explanation about the origin of life on Earth, and 26\% considered that evolution and creationism are in harmony. Agreement with factual explanations about the origin of life on Earth and its place in the universe increases according to biology majors' academic level at both RWU (Fig. 9c, 

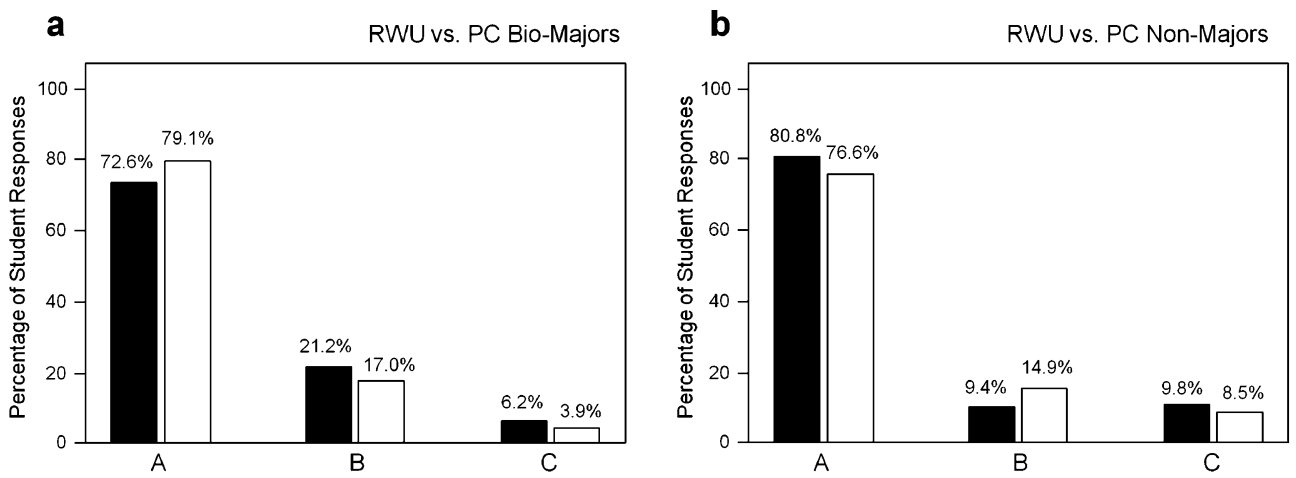

C RWUvs. PC Bio-Freshman
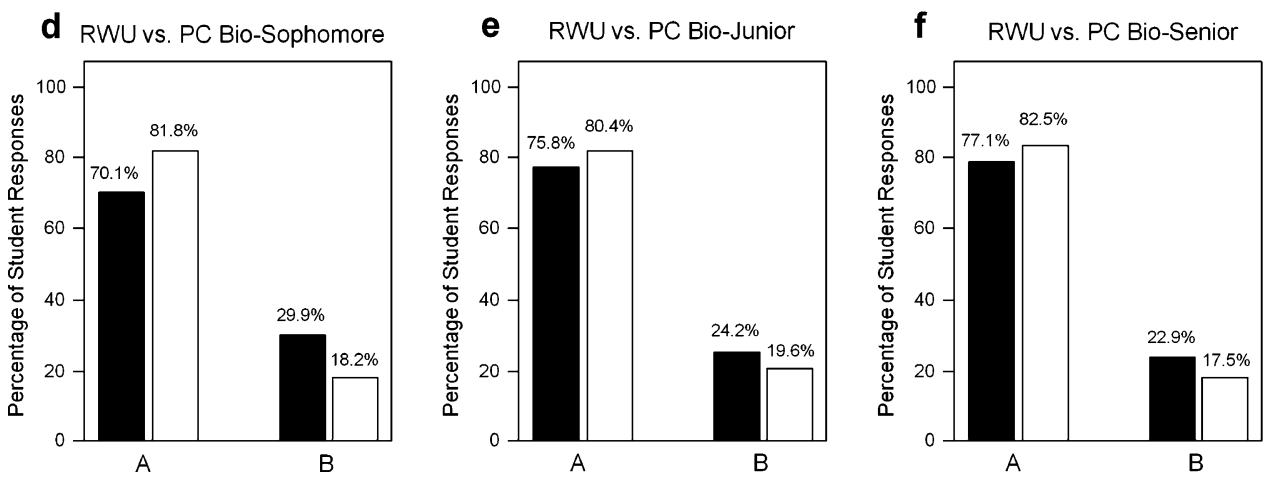

Fig. 5 Percentage of RWU (black bars) versus PC (white bars) students who agree with one of the following statements concerning evolution in science exams: $A=\mathrm{I}$ have no problem answering questions concerning evolution, $B=$ science exams should always include some questions concerning evolution, $C=$ do not know enough to say. Comparisons between institutions: a biology majors (RWU $n=237$, PC $n=212$ ), Chi-square $=1.058, d f=2, P=0.58$. b Nonmajors (RWU $n=239$, PC $n=143$ ), Chi-square $=1.649, d f=2$,

$P=0.43$. c Biology freshman (RWU $n=93, \mathrm{PC} n=70$ ), Chi-square $=$ $0.139, d f=1, P=0.71$. d Biology sophomore (RWU $n=74$, PC $n=34$ ), Chi-square $=3.317, d f=1, P=0.06$. e Biology junior (RWU $n=33, \mathrm{PC}$ $n=50$ ), Chi-square $=0.262, d f=1, P=0.60$. f Biology senior (RWU $n=$ 37, PC $n=58)$, Chi-square $=0.781, d f=1, P=0.37$. Combined freshman, sophomore, junior, and senior responders (mean of RWU + PC) for $A$ vs. $B$ differ in $\mathbf{c}$ to $\mathbf{f}$, sign test two-tail $P \leq 0.05$

Chi-square $=17.663, d f=6, P=0.007)$ and PC (Fig. 9d, Chisquare $=9.355, d f=3, P=0.02)$, from $69 \%$ freshmen to $89 \%$ seniors at RWU $(r=0.98, P=0.014)$ and from $63 \%$ freshman to $81 \%$ senior at PC $(r=0.99, P=0.007)$. Although $25 \%$ of RWU and $36 \%$ of PC freshman thought that hearing about evolution makes no difference because evolution and creationism are in harmony, this opinion dropped to $7 \%(r=0.98, P=0.013)$ and $18 \%(r=0.99, P=$ $0.007)$ among seniors, respectively.

\section{Students' Position About the Teaching of Human Evolution} Biology majors versus nonmajors agreed in their views about the teaching of human evolution at both RWU (Fig. 10a, Chi-square $=4.808, d f=2, P=0.09$ ) and $\mathrm{PC}$ (Fig. 10b, Chi-square $=2.485, d f=2, P=0.28$ ). At RWU, $78 \%$ of the combined student responders (mean biology majors + nonmajors) preferred science courses where evolution is discussed comprehensively and humans are part of it; $10 \%$ preferred evolution discussions about plants and animals but not humans, and $12 \%$ did not know enough to say. At PC, $87 \%$ of the combined student responders welcomed the teaching of human evolution; $6 \%$ preferred

evolution discussions about plants and animals but not humans, and $8 \%$ did not know enough to say. Agreement with science courses where evolution is discussed comprehensively and humans are part of it augmented only $\approx 10 \%$ according to biology majors' academic level at both RWU (Fig. 10c, Chi-square $=13.676, d f=6, P=0.03$ ) and $\mathrm{PC}$ (Fig. 10d, Chi-square $=11.702, d f=3, P=0.008$ ), from $82 \%$ freshmen to $92 \%$ of seniors at RWU $(r=0.75, P=0.24)$ and from $87 \%$ freshman to $96 \%$ of seniors at PC ( $r=0.74, P=$ 0.25 ). Although $11 \%$ of RWU and $12 \%$ of PC freshmen preferred evolution discussions about plants and animals but not humans, this opinion dropped to $2 \%(r=0.79, P=0.21)$ and $3 \%(r=0.74, P=0.25)$ among seniors, respectively.

Evolution in Science Exams Biology majors versus nonmajors differed in their opinions concerning the inclusion of evolution in science exams at RWU (Fig. 11a, Chisquare $=10.508, d f=3, P=0.01$ ), but they did not at PC (Fig. 11b, Chi-square $=2.069, d f=2, P=0.35$ ). At RWU, $70 \%$ of the combined student responders (mean biology majors + nonmajors) had no problem answering questions concerning evolution in exams; $20 \%$ of biology majors 
Fig. 6 Percentage of RWU (black bars) versus PC (white bars) students who believe one of the following statements describes them best: $A=\mathrm{I}$ accept evolution and express it openly regardless of others' opinions, $B=$ no opinion, $C=\mathrm{I}$ accept evolution but do not discuss it openly to avoid conflicts with friends and family, $D=\mathrm{I}$ believe in creationism and express it openly regardless of others' opinions, $E=\mathrm{I}$ believe in creationism but do not discuss it openly to avoid conflicts with friends and family. Comparisons between institutions: a biology majors (RWU $n=237, \mathrm{PC} n=$ 212), Chi-square $=7.696$, $d f=4, P=0.10$. b Nonmajors (RWU $n=239$, PC $n=143$ ), Chi-square $=5.315, d f=4$, $P=0.25$. c Biology freshman (RWU $n=93$, PC $n=70$ ), Chi-square $=17.651, d f=3$, $P \leq 0.001$; asterisk indicates sign test two-tail pairwise comparison $P \leq 0.05$. d Biology sophomore (RWU $n=74$, PC $n=34$ ), Chi-square $=1.358, d f=2, P=$ 0.50 . e Biology junior (RWU $n=33$, PC $n=50)$, Chi-square $=$ 1.572, $d f=2, P=0.45$. f Biology senior (RWU $n=37, \mathrm{PC} n=58$ ), Chi-square $=0.457, d f=2$, $P=0.79$
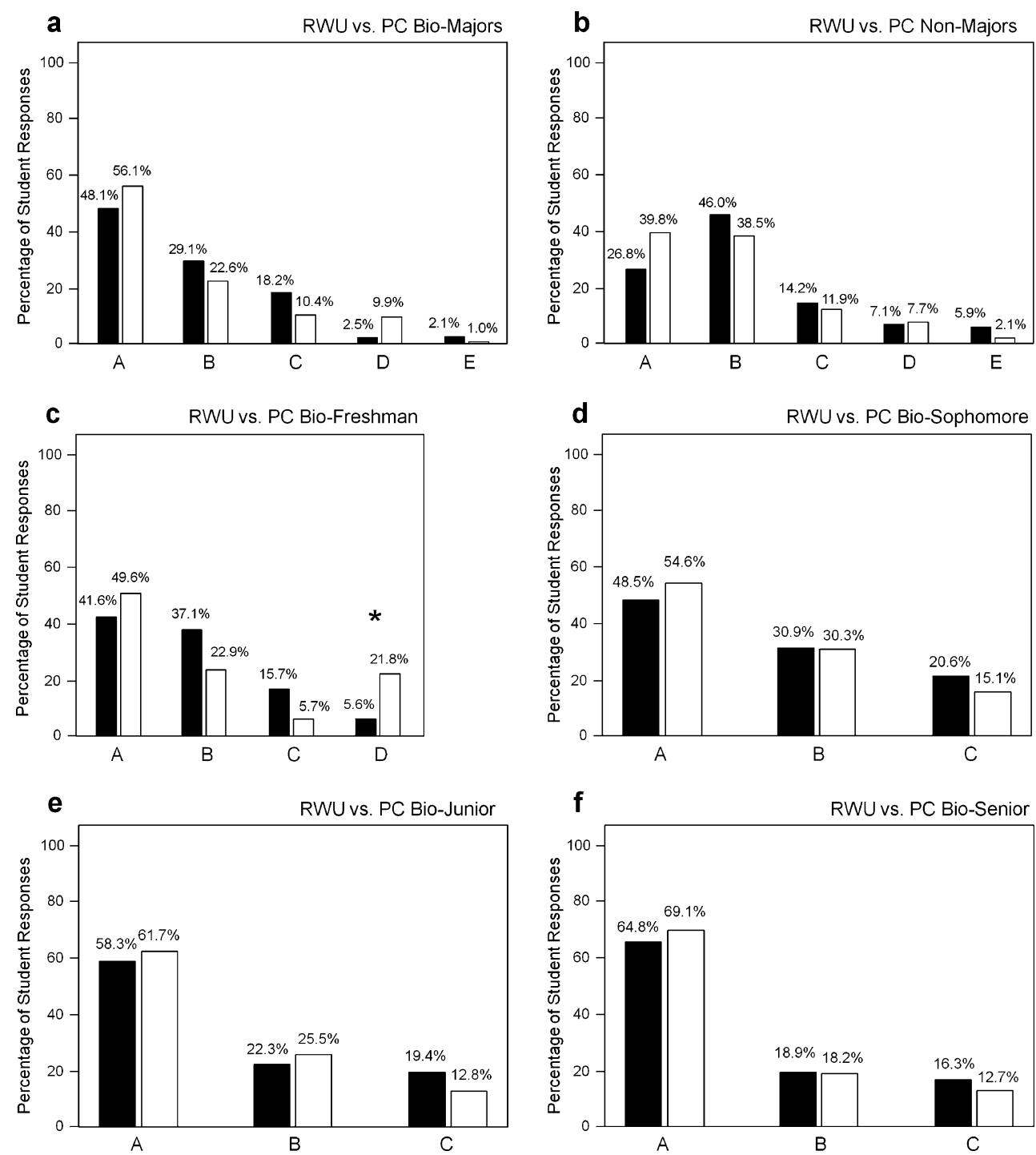

versus $8 \%$ of nonmajors considered that exams should always include some questions concerning evolution (sign test two-tail pairwise comparison $P \leq 0.05$ ); $4 \%$ of biology majors versus $13 \%$ of nonmajors did not know enough to say (sign test two-tail pairwise comparison $P \leq 0.05$ ), and $7 \%$ of the combined student responders preferred not to answer questions concerning evolution. At PC, 78\% of the combined student responders welcomed questions concerning evolution in exams; $16 \%$ thought that exams should always include some questions concerning evolution, and $6 \%$ did not know enough to say. Agreement with answering questions concerning evolution in science exams was equally high among all biology majors' academic level at both RWU (mean 71\%; Fig. 11c, Chi-square $=15.455$, $d f=6, P=0.01$ ) and PC (mean 82\%; Fig. 11d, Chi-square $=$ $0.542, d f=3, P=0.91$ ). Support for the idea that science exams should always include some questions concerning evolution varied with no definite trend at either RWU or PC.
Students' Willingness to Discuss Evolution Biology majors versus nonmajors differed in their willingness to offer opinions about evolution at RWU (Fig. 12a, Chi-square= 13.833, $d f=4, P=0.008$ ) but they did not at PC (Fig. 12b, Chi-square $=7.528, d f=4, P=0.11)$. At RWU, $48 \%$ of biology majors versus $26 \%$ of nonmajors indicated that they accept evolution and express it openly regardless of others' opinions (sign test two-tail pairwise comparison $P \leq$ $0.05) ; 29 \%$ of biology majors versus $46 \%$ of nonmajors preferred not to comment on this issue; $16 \%$ of the combined student responders (mean biology majors + nonmajors) admitted that they accept evolution but do not discuss it openly to avoid conflicts with friends and family; the remaining $9 \%$ either believe in creationism and express it openly regardless of others' opinions or believe in creationism but do not discuss it openly to avoid conflicts with friends and family. At PC, $48 \%$ of the combined student responders indicated that they accept evolution and express it openly; $30 \%$ preferred not to comment on this 

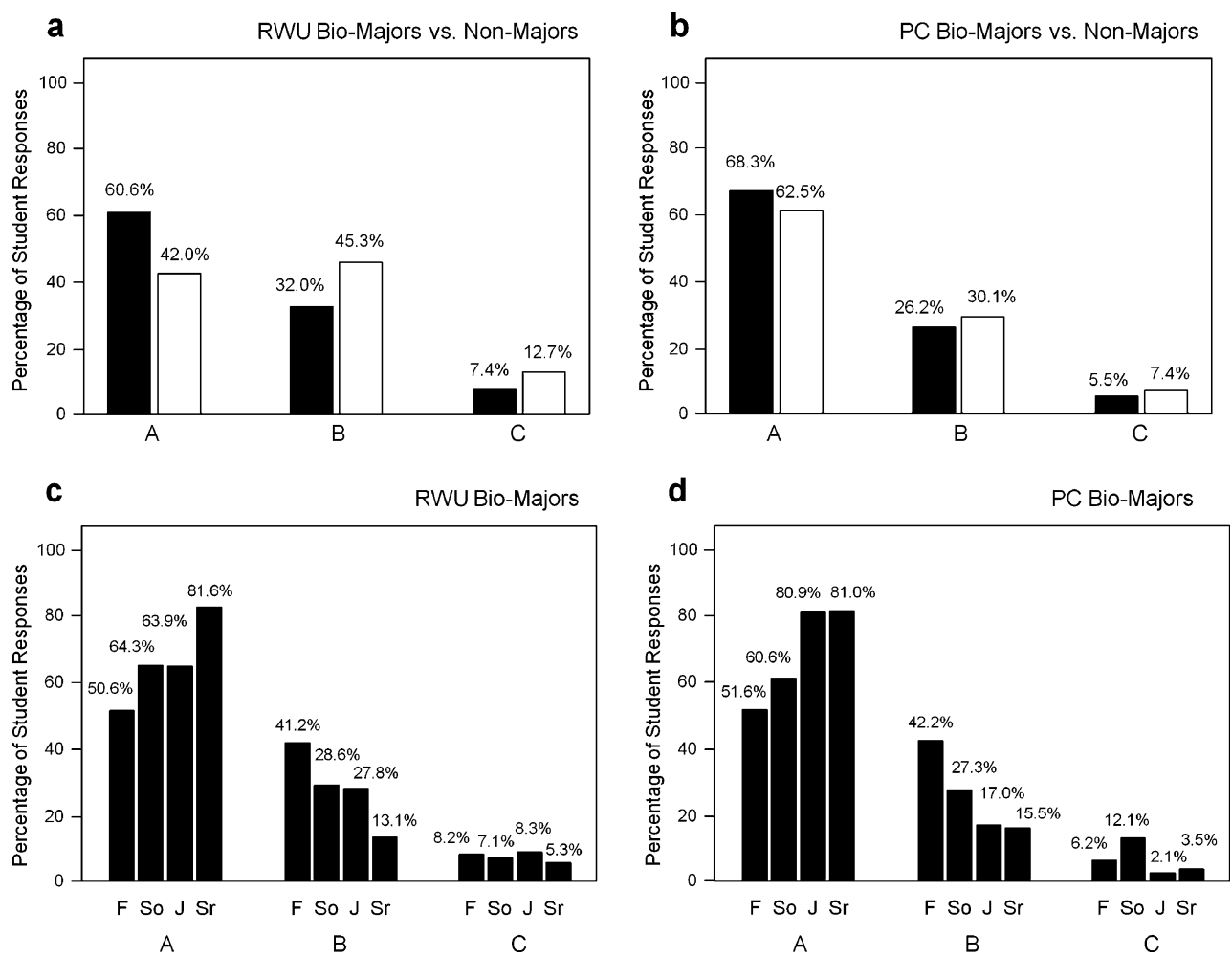

Fig. 7 Percentage of biology majors (black bars) versus nonmajors (white bars) who consider one of the following explanations about the origin and development of life on Earth should be taught in science classes: $A=$ evolution, $B=$ equal time to evolution, creationism, intelligent design, $C=$ do not know enough to say. Comparisons within institutions: a RWU biology majors $(n=237)$ versus nonmajors $(n=239)$, Chi-square $=7.5, d f=2, P=0.02$. b PC biology majors $(n=$ 212) versus nonmajors $(n=143)$, Chi-square $=0.553, d f=2, P=0.75$.

issue; $11 \%$ admitted they accept evolution but do not discuss it openly; the remaining $11 \%$ either believe in creationism and express it openly or do not discuss it openly. Willingness to discuss evolution increased according to biology majors' academic level at both RWU (Fig. 12c, Chi-square $=14.535, d f=6, P=0.02$ ) and PC (Fig. 12d, Chi-square $=34.242, d f=9, P \leq 0.001$ ), from $44 \%$ of freshmen to $64 \%$ of seniors at RWU $(r=0.99$, $P=0.009)$ and from $48 \%$ of freshmen to $66 \%$ of seniors at PC ( $r=0.98, P=0.013)$. Although $39 \%$ RWU and $23 \%$ PC freshmen preferred not to comment on this topic, this view dropped to $18 \%(r=0.98, P=0.015)$ and $17 \%(r=0.61$, $P=0.38)$ among seniors, respectively.

\section{Discussion}

Interinstitutional Comparisons

Students at the secular RWU and Catholic PC had both similar and contrasting views concerning evolution. Similarities included: $76 \%$ of biology majors or $76 \%$ of

c RWU within-biology-majors comparisons: $F=$ freshman $(n=93)$, $S o=$ sophomore $(n=74), J=$ junior $(n=33), S r=$ senior $(n=37)$, Chisquare $=22.542, d f=6, P \leq 0.001$; linear regression choice $A$ : $r=0.94$, $P=0.059$, choice $B: r=0.95, P=0.044$. d PC within-biology-majors comparisons: $F=$ freshman $(n=70)$, So $=$ sophomore $(n=34), J=$ junior $(n=50), S r=$ senior $(n=58)$, Chi-square $=35.809, d f=6, P \leq$ 0.001 ; linear regression choice $A: r=0.94, P=0.054$, choice $B$ : $r=0.94, P=0.052$

nonmajors (means RWU + PC) valued the factual explanation evolution provides about the origin of life and its place in the universe (Fig. 3a, b, choice A); $86 \%$ of biology majors or $79 \%$ of nonmajors (means RWU + PC) preferred science courses where human evolution is discussed (Fig. 4ab, choice A), and $76 \%$ of biology majors or $79 \%$ of nonmajors (means RWU + PC) welcomed questions concerning evolution in exams (Fig. 5a, b, choice A). Biology freshmen, sophomores, juniors, or seniors had high acceptance of evolution (63-96\%) in these three areas at both institutions (Figs. 3, 4, and 5c-f, choice A). Note that $23 \%$ of biology majors or $24 \%$ of nonmajors (means RWU + PC) considered that evolution and creationism are in harmony (Fig. 3ab, choice B). Biology freshmen $(32 \%)$ or sophomores $(24 \%)$ favored this view more than juniors $(18 \%)$ or seniors $(13 \%)$ at both institutions (means RWU + PC; Fig. 3c-f, choice B). Contrasting views included: $64 \%$ of biology majors (mean RWU + PC; Fig. 1a, choice A) or $42 \%$ of RWU versus $62 \%$ of PC nonmajors (Fig. 1b, choice A) supported the exclusive teaching of evolution in science classes; PC nonmajors have particularly strong philosophic-scientific foundations. 

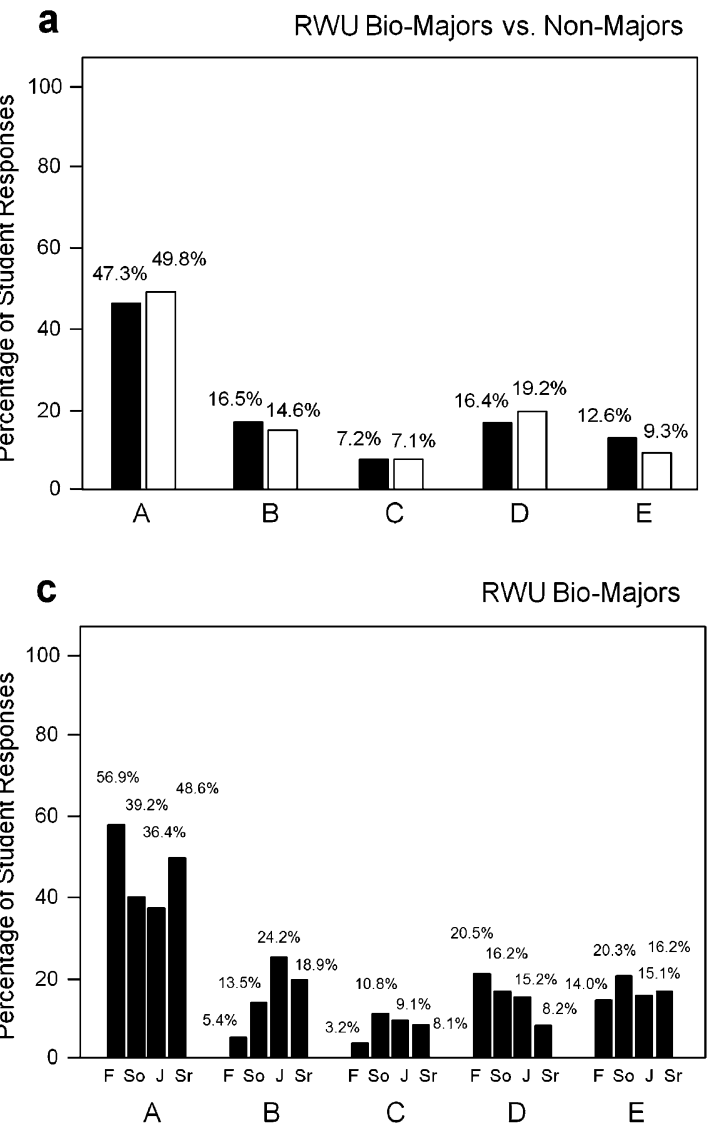

Fig. 8 Percentage of biology majors (black bars) versus nonmajors (white bars) who consider that one of the following statements is consistent with ID: $A=$ no opinion, $B=$ ID is religious doctrine consistent with creationism, $C=$ ID is a scientific alternative to evolution and of equal scientific validity among scientists, $D=$ ID is a scientific theory about the origin and evolution of life on Earth, $E=$ ID is not scientific but has been proposed to counter evolution based on false scientific claims. Comparisons within institutions: a RWU

Note that $29 \%$ of biology majors or $38 \%$ of nonmajors (means RWU + PC) favored equal time in the science class to evolution, creationism, and ID (Fig. 1ab, choice B). Biology freshmen (42\%) or sophomores (28\%) favored this view more than juniors $(22 \%)$ or seniors $(14 \%)$ at both institutions (means RWU + PC; Fig. 1c-f, choice B). Only $52 \%$ of biology majors (mean RWU + PC; Fig. 6a, choice A) or 33\% of nonmajors (mean RWU + PC; Fig. 6b, choice A) admitted to accepting evolution openly regardless of others' opinions. Few biology freshmen (11\%), sophomores $(18 \%)$, juniors $(16 \%)$, or seniors $(15 \%)$ admitted to accepting evolution privately to avoid conflicts with friends and family (means RWU + PC; Fig. 6c-f, choice $\mathrm{C}$ ). The overall belief in creationism was low: $6 \%$ of RWU or PC biology majors and $7 \%$ of RWU or PC nonmajors (means RWU + PC) admitted to believing in creationism and expressing it openly, while $2 \%$ of RWU or PC biology majors and $4 \%$ of RWU or PC nonmajors (means RWU + PC) acknowledged believing in creation-
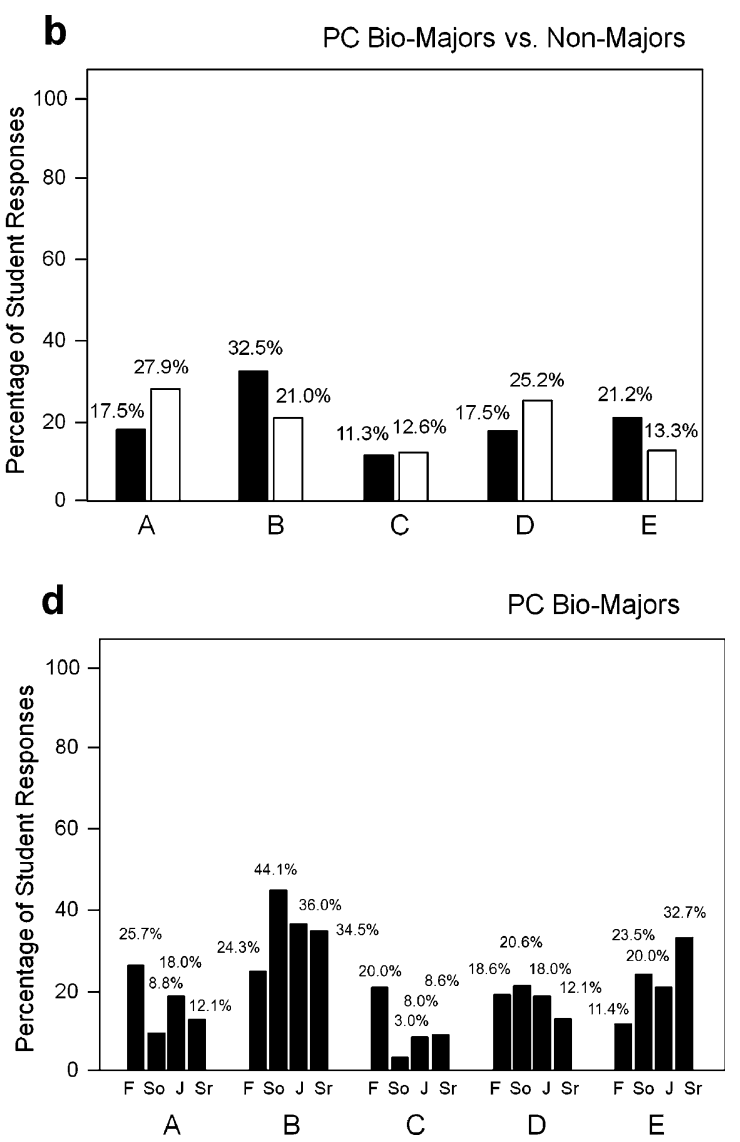

biology majors $(n=237)$ versus nonmajors $(n=239)$, Chi-square $=$ $1.202, d f=4, P=0.87$. b PC biology majors $(n=212)$ versus nonmajors $(n=143)$, Chi-square $=8.024, d f=4, P=0.09$. c RWU within-biologymajors comparisons: $F=$ freshman $(n=93)$, $S o=$ sophomore $(n=74)$, $J=$ junior $(n=33), S r=$ senior $(n=37)$, Chi-square $=30.305, d f=12$, $P=0.003$. d PC within-biology-majors comparisons: $F=$ freshman $(n=70), S o=$ sophomore $(n=34), J=$ junior $(n=50), S r=$ senior $(n=58)$, Chi-square $=45.574, d f=12, P \leq 0.001$

ism but not discussing it openly (Fig. 6a, b, choices D or E). Note that $21 \%$ of PC biology freshman (data alone) admitted to believing in creationism and expressing it openly (Fig. 6c, choice D).

The combined responses of biology majors or nonmajors (means RWU + PC) who accept evolution and express it openly plus those who accept evolution privately showed contrasting overall acceptance of evolution between biology majors $(66 \%$; Fig. 6a, choices A $+C)$ and nonmajors $(46 \%$; Fig. 6b, choices $\mathrm{A}+\mathrm{C})$. Freshman biology majors alone (mean RWU + PC; Fig. 6c, choices A + C) showed higher $(56 \%)$ overall acceptance of evolution than nonmajors (46\%; mean RWU + PC; Fig. 6b, choices A + C), suggesting a precollege background in support of evolution, probably linked to household influence and/or high school science education. Overall acceptance of evolution was particularly high when compared to the rest of biology majors alone: sophomore $(70 \%)$, junior $(76 \%)$, or senior (82\%; means RWU + PC; Fig. 6d-f, choices A + C). 

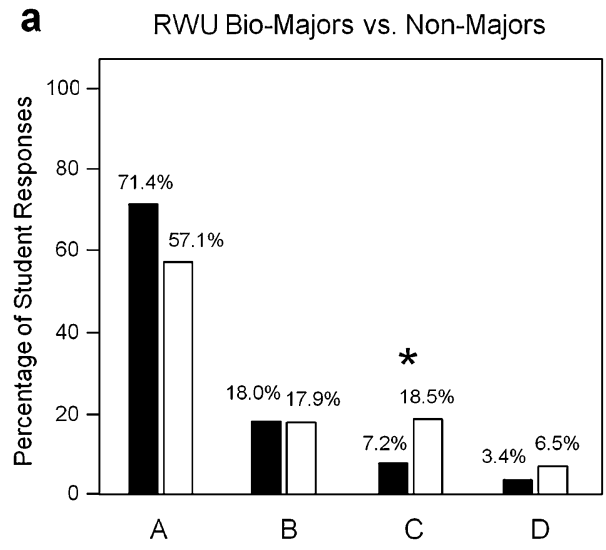

C

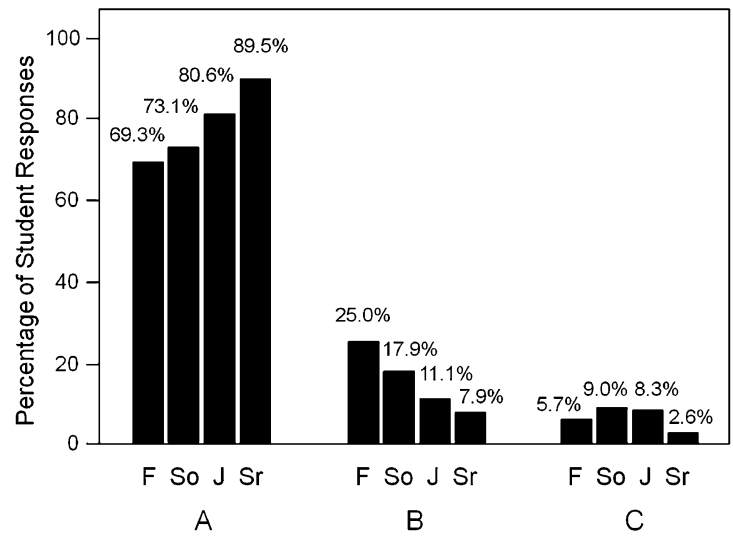

b

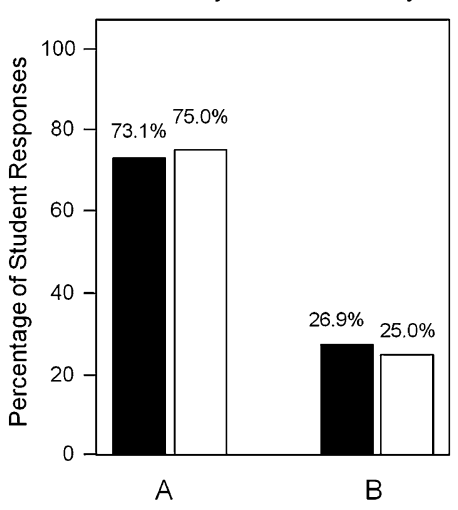

d

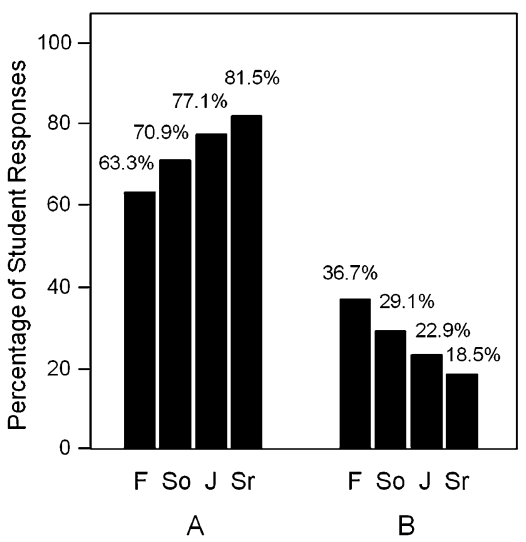

Fig. 9 Percentage of biology majors (black bars) versus nonmajors (white bars) who think one of the following statements fits best their position concerning evolution: $A=$ hearing about evolution makes me appreciate the factual explanation about the origin of life on Earth and its place in the universe, $B=$ hearing about evolution makes no difference to me because evolution and creationism are in harmony, $C=$ do not know enough to say, $D=$ hearing about evolution makes me uncomfortable because it is in conflict with my faith. Comparisons within institutions: a RWU biology majors $(n=237)$ versus nonmajors $(n=239)$, Chi-square $=8.651, d f=3, P=0.03$; asterisk indicates sign test two-tail pairwise comparison $P \leq 0.05$. b PC biology majors

A notable difference between RWU and PC concerned the students' views about ID: $47 \%$ of RWU versus $17 \%$ of PC biology majors (Fig. 2a, choice A) and $49 \%$ of RWU versus $27 \%$ of PC nonmajors (Fig. 2b, choice A) had no opinion about ID. However, $16 \%$ of RWU versus $32 \%$ of PC biology majors thought ID is a religious doctrine consistent with creationism (Fig. 2a, choice B), a view supported by $14 \%$ of RWU versus $24 \%$ of PC freshmen, $20 \%$ of RWU versus $44 \%$ of PC sophomores, $15 \%$ of RWU versus $36 \%$ of PC juniors, or $16 \%$ of RWU versus $34 \%$ of PC seniors (Fig. 2c-f, choice B). These responses suggest different levels of knowledge about and perception of ID between institutions, but not necessarily endorsement or rejection of it (but see below). The combined responses of students who perceived ID as both scientific alternative to evolution of $(n=212)$ versus nonmajors $(n=143)$, Chi-square $=0.026, d f=1, P=$ 0.87 ; combined student responders (mean of biology majors + nonmajors) for $A$ vs. $B$ differ, sign test two-tail $P \leq 0.05$. c RWU within-biology-majors comparisons: $F=$ freshman $(n=93)$, So $=$ sophomore $(n=74), J=$ junior $(n=33), S r=\operatorname{senior}(n=37)$, Chi-square $=$ 17.663, $d f=6, P=0.007$; linear regression choice $A: r=0.98, P=0.014$, choice $B: r=0.98, P=0.013$. d PC within-biology-majors comparisons: $F=$ freshman $(n=70), S o=$ sophomore $(n=34), J=$ junior $(n=50), S r=$ senior $(n=58)$, Chi-square $=9.335, d f=3, P=0.02$; linear regression choice $A$ : $r=0.99, P=0.007$, choice $B: r=0.99, P=0.007$

equal scientific validity among scientists and scientific theory about the origin and evolution of life on Earthwhich may imply endorsement of or sympathy for ID were $24 \%$ of RWU or $29 \%$ of PC biology majors (Fig. 2a, choices $\mathrm{C}+\mathrm{D}$ ) and $26 \%$ of RWU or $38 \%$ of PC nonmajors (Fig. 2b, choices C + D). Biology freshmen (24\% RWU, $39 \%$ PC), sophomores (27\% RWU, 24\% PC), juniors (24\% RWU, 28\% PC), or seniors (16\% RWU, 21\% PC) agreed with this view (Fig. 2d-f, choices C + D). Only 17\% of biology majors or $11 \%$ of nonmajors (means RWU + PC) rejected ID for considering it not scientific but proposed to counter evolution based on false scientific claims (Fig. 2a, b, choice E); $8 \%$ of biology freshmen, 19\% of sophomores, $22 \%$ of juniors, or $26 \%$ of seniors favored this view at both institutions (means RWU + PC; Fig. 2c-f, choice E). 

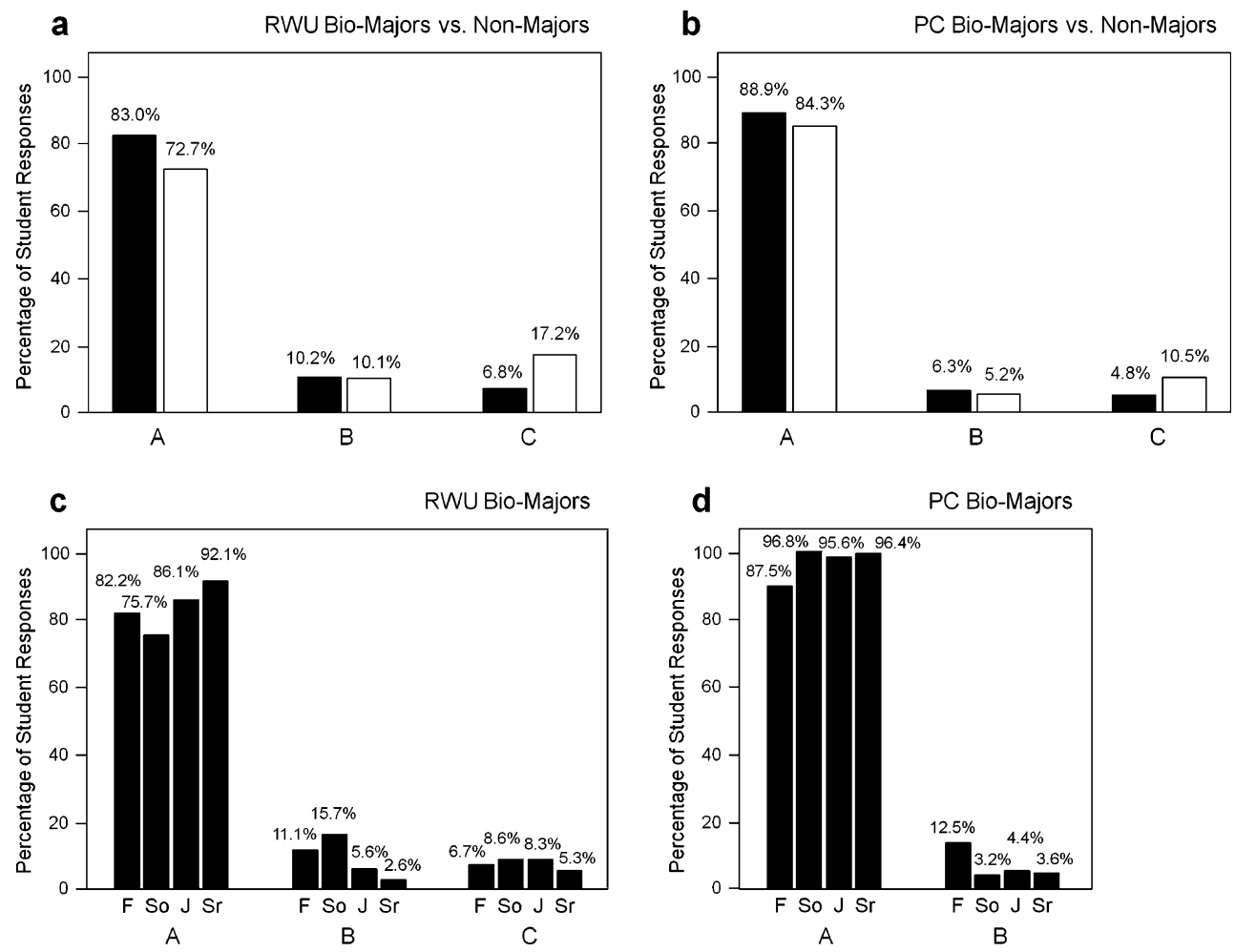

Fig. 10 Percentage of biology majors (black bars) versus nonmajors (white bars) who agree with one of the following statements concerning their own education: $A=\mathrm{I}$ prefer science courses where evolution is discussed comprehensively and humans are part of it, $B=\mathrm{I}$ prefer science courses where plant and animal evolution is discussed but not human evolution, $C=$ do not know enough to say. Comparisons within institutions: a RWU biology majors $(n=237)$ versus nonmajors $(n=239)$, Chi-square $=4.808, d f=2, P=0.09$. b PC biology majors $(n=212)$ versus nonmajors $(n=143)$, Chi-square $=$

2.485, $d f=2, P=0.28$. c RWU within-biology-majors comparisons: $F=$ freshman $(n=93), S o=$ sophomore $(n=74), J=$ junior $(n=33), S r=$ senior $(n=37)$, Chi-square $=13.676, d f=6, P=0.03$; linear regression choice $A: r=0.75, P=0.24$, choice $B: r=0.79, P=0.21$. d PC within biology-majors comparisons: $F=$ freshman $(n=70)$, $S o=$ sophomore $(n=34), J=$ junior $(n=50), S r=$ senior $(n=58)$, Chi-square $=11.702$, $d f=3, P=0.008$; linear regression choice $A: r=0.74, P=0.25$, choice $B: r=0.74, P=0.25$

\section{Intrainstitutional Comparisons}

Acceptance of evolution was both similar and contrasting when comparing biology majors versus nonmajors within RWU or PC: $60 \%$ of RWU biology majors versus $42 \%$ of RWU nonmajors or $65 \%$ of PC responders (mean biology majors + nonmajors) supported the exclusive teaching of evolution in science classes (Fig. 7a, b, choice A); $71 \%$ of RWU biology majors versus $57 \%$ of RWU nonmajors or $74 \%$ of PC responders (mean biology majors + nonmajors) valued the factual explanation evolution provides about the origin of life and its place in the universe (Fig. 9a, b, choice A); $78 \%$ of RWU or $87 \%$ of PC responders (means biology majors + nonmajors) preferred science courses where human evolution is discussed (Fig. 10a, b, choice A); $70 \%$ of RWU or $78 \%$ of PC responders (means biology majors + nonmajors) welcomed questions concerning evolution in exams (Fig. 11a, b, choice A); and $48 \%$ of RWU biology majors versus $26 \%$ of RWU nonmajors or $56 \%$ of PC biology majors versus $39 \%$ of PC nonmajors admitted to accepting evolution openly regardless of others'

opinions (Fig. 12a, b, choice A). Acceptance of evolution in four of these five areas increased gradually with academic level at each institution, from the freshman to the senior year: support to the exclusive teaching of evolution in science class (RWU or PC $50 \%$ of freshmen to $81 \%$ of seniors; Fig. 7c, d, choice A), appreciation for the factual explanation evolution provides about the origin of life and its place in the universe (RWU $69 \%$ of freshmen to $89 \%$ of seniors, PC $63 \%$ of freshmen to $81 \%$ of seniors; Fig. 9c, d, choice A), preference for science courses where human evolution is discussed (RWU $82 \%$ of freshmen to $92 \%$ of seniors, PC $87 \%$ of freshmen to $96 \%$ of seniors; Fig. 10c, d, choice A; despite these high percentage values, the $\approx 10 \%$ augment/institution/academic-level conveyed high $r$ coefficients but nonsignificant $P$ value; results above), and willingness to accept evolution openly (RWU 44\% of freshmen to $64 \%$ of seniors, PC $48 \%$ of freshmen to $66 \%$ of seniors; Fig. 12c, d, choice A). Preference for questions concerning evolution in exams was evenly high across academic levels (mean RWU 71\%, mean PC 82\%; Fig. 11c, d, choice A). 

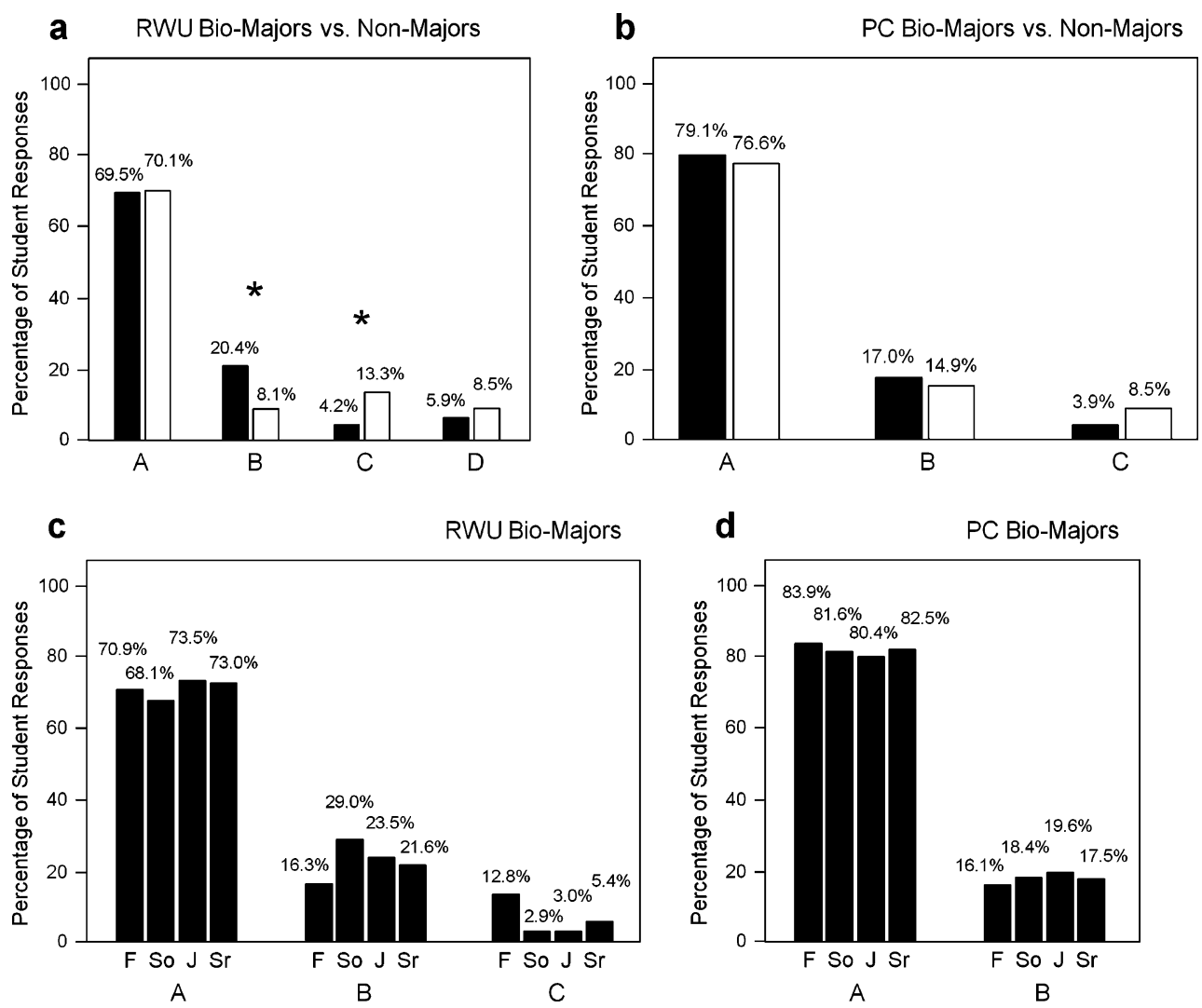

Fig. 11 Percentage of biology majors (black bars) versus nonmajors (white bars) who agree with one of the following statements concerning evolution in science exams: $A=\mathrm{I}$ have no problem answering questions concerning evolution, $B=$ science exams should always include some questions concerning evolution, $C=$ do not know enough to say, $D=$ I prefer to not answer questions concerning evolution. Comparisons within institutions: a RWU biology majors $(n=237)$ versus nonmajors $(n=239)$, Chi-square $=10.508, d f=3, P=$ 0.01 ; asterisks indicate sign test two-tail pairwise comparisons $P \leq$

Note that $32 \%$ of RWU biology majors versus $45 \%$ of RWU nonmajors or $28 \%$ of PC responders (mean biology majors + nonmajors) favored equal time in the science class to evolution, creationism, and intelligent design (Fig. 7a, b, choice B). Biology majors' agreement with this view decreased gradually with academic level at each institution (RWU $41 \%$ of freshmen to $13 \%$ of seniors, PC $42 \%$ of freshmen to $15 \%$ of seniors; Fig. 7c, d, choice B). About one fifth $(18 \%)$ of RWU and one quarter $(26 \%)$ of PC responders (means biology majors + nonmajors) considered that evolution and creationism are in harmony (Fig. 9a, b, choice B), an opinion that decreased gradually with academic level (RWU 25\% of freshmen to $7 \%$ of seniors, PC $36 \%$ of freshmen to $18 \%$ of seniors; Fig. $9 \mathrm{c}$, d, choice B). Receptiveness to answer questions concerning evolution plus agreement with always having such questions in exams was particularly high: $90 \%$ of RWU biology majors versus $78 \%$ of RWU nonmajors or $96 \%$ of PC biology majors versus $92 \%$ of PC nonmajors (Fig. 11a, b,
0.05. b PC biology majors $(n=212)$ versus nonmajors $(n=143)$, Chi-square $=2.069, d f=2, P=0.35$. c RWU within-biology-majors comparisons: $F=$ freshman $(n=93)$, So $=$ sophomore $(n=74), J=$ junior ( $n=33), S r=$ senior $(n=37)$, Chi-square $=15.455, d f=6, P=$ 0.01. d PC within-biology-majors comparisons: $F=$ freshman $(n=70)$, $S o=$ sophomore $(n=34), J=$ junior $(n=50), S r=$ senior $(n=58)$, Chi-square $=0.542, d f=3, P=0.91$; combined biology majors (mean of $\mathrm{F}+\mathrm{So}+\mathrm{J}+\mathrm{Sr}$ ) for $A$ vs. $B$ differ, sign test two-tail $P \leq 0.05$

choices $\mathrm{A}+\mathrm{B})$, an opinion shared by all biology majors' academic levels (mean RWU 94\%, mean PC 100\%; Fig. 11c, d, choices A + B).

Only $16 \%$ of RWU or $11 \%$ of PC responders (means biology majors + nonmajors) admitted accepting evolution but not discussing it openly to avoid conflicts with friends and family (Fig. 12a, b, choice C). Except for PC freshmen $(21 \%)$, very few other biology majors admitted to believing in creationism and expressing it openly (Fig. 12d, choice D). The combined responses of students who accept evolution and express it openly plus those who accept evolution privately showed contrasting overall acceptance of evolution within RWU (66\% of biology majors versus $41 \%$ of nonmajors; Fig. $12 \mathrm{a}$, choices $\mathrm{A}+\mathrm{C}$ ) and PC (67\% of biology majors versus $52 \%$ of nonmajors; Fig. 12b, choices $\mathrm{A}+\mathrm{C}$ ). RWU freshman biology majors alone (Fig. 12c, choices A + C) showed higher $(61 \%)$ overall acceptance of evolution than RWU nonmajors (41\%) (Fig. 12a, choices A + C), suggesting a precollege 

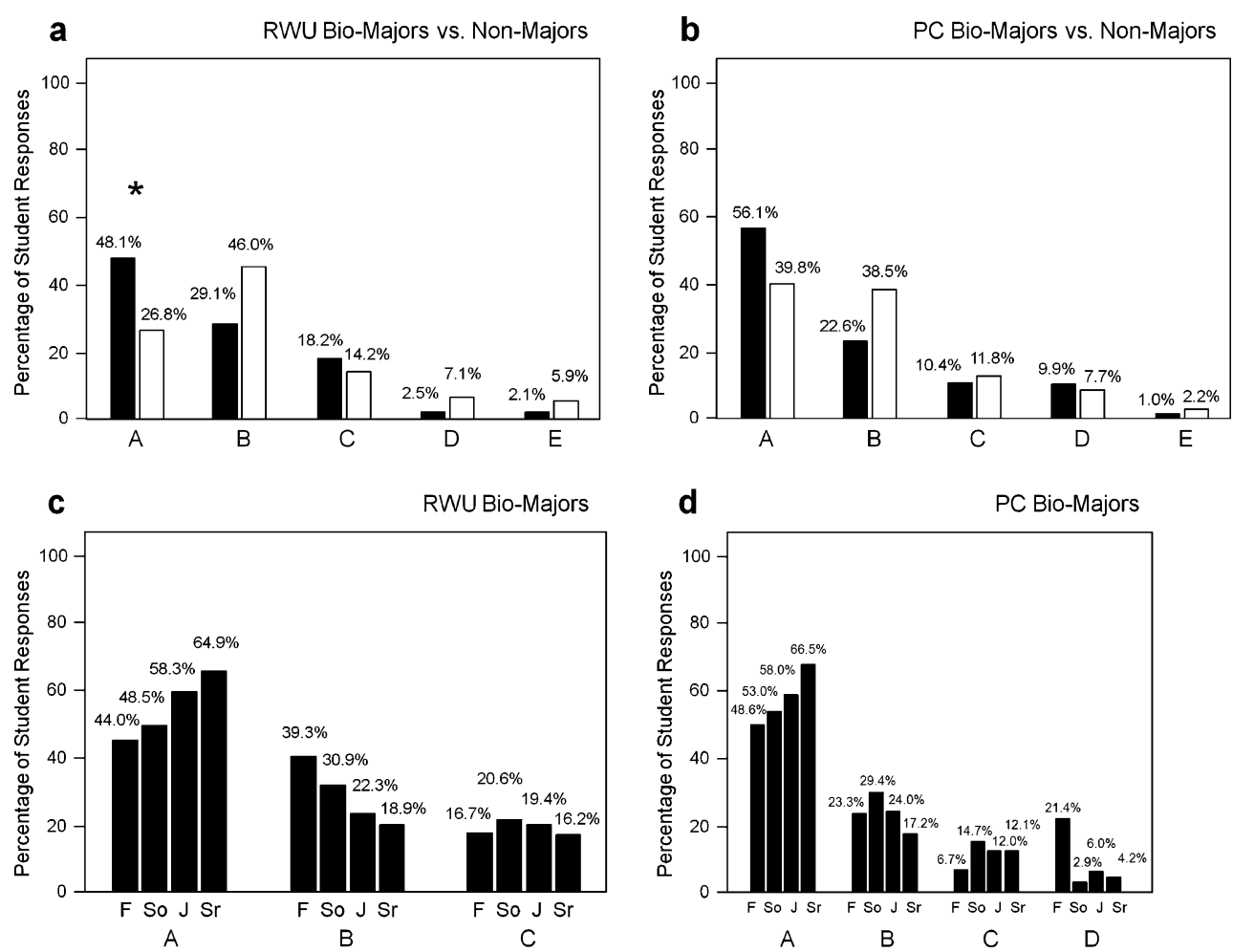

Fig. 12 Percentage of biology majors (black bars) versus nonmajors (white bars) who believe one of the following statements describes them best: $A=\mathrm{I}$ accept evolution and express it openly regardless of others' opinions, $B=$ no opinion, $C=\mathrm{I}$ accept evolution but do not discuss it openly to avoid conflicts with friends and family, $D=\mathrm{I}$ believe in creationism and express it openly regardless of others' opinions, $E=$ I believe in creationism but do not discuss it openly to avoid conflicts with friends and family. Comparisons within institutions: a RWU biology majors $(n=237)$ versus nonmajors $(n=239)$, Chi-square $=13.833, d f=4, P=0.008$; asterisk indicates sign test two-

background in support of evolution, probably linked to household influence and/or high school science education. However, PC freshman biology majors alone (Fig. 12d, choices A + C) showed similar (55\%) overall acceptance of evolution to PC nonmajors (52\%; Fig. 12b, choices A + C). Overall acceptance of evolution within RWU or PC was particularly high when looking at the rest of biology majors alone: sophomore (RWU 69\%, PC 68\%), junior (RWU $78 \%$, PC $70 \%$ ), or senior (RWU 81\%, PC 79\%; Fig. 12cd, choices $\mathrm{A}+\mathrm{C}$ ).

Gradual exposure to upper-division biology courses with evolutionary content among biology majors might explain their increasing acceptance of evolution from freshman to senior year at both institutions (see notes Table 1). We had no accurate way to assess nonmajors' longitudinal range of views about evolution because science course requirements for nonmajors differ between RWU and PC (e.g., RWU students attend a single core course, mainly during their sophomore year, with introductory evolutionary content, while PC students attend two natural science core courses,

tail pairwise comparison $P \leq 0.05$. b PC biology majors $(n=212)$ versus nonmajors $(n=143)$, Chi-square $=7.528, d f=4, P=0.11$. c RWU within-biology-majors comparisons: $F=$ freshman $(n=93)$, So $=$ sophomore $(n=74), J=$ junior $(n=33), S r=$ senior $(n=37)$, Chi-square $=$ 14.535, $d f=6, P=0.02$; linear regression choice $A: r=0.99, P=0.009$, choice $B$ : $r=0.98, P=0.015$. d PC within biology-majors comparisons: $\mathrm{F}=$ freshman $(n=70), S o=$ sophomore $(n=34), J=$ junior $(n=50), S r=$ senior $(n=58)$, Chi-square $=34.242, d f=9, P \leq 0.001$; linear regression choice $A$ : $r=0.98, P=0.013$, choice $B: r=0.61, P=0.38$

mainly during the junior year, chosen from a diverse list; Table 1). We suspect that nonmajors may not increase their acceptance of evolution chronologically as much as biology majors, considering that nonmajors either never reached the freshman biology majors' baseline support of evolution (RWU's) or coincided only with the freshman's level of acceptance of evolution (PC's), but not with the later years (data above). We point out, however, that nonmajors are willing to learn evolution: $57 \%$ of RWU or $75 \%$ of PC responders appreciate factual explanations about the origin of life on Earth and its place in the universe (Fig. 9a, b, choice A); $72 \%$ of RWU or $84 \%$ of PC students surveyed prefer science courses where evolution is discussed comprehensively and humans are part of it (Fig. 10a, b, choice A), and $70 \%$ of RWU or $76 \%$ of PC students in the study have no problem answering questions concerning evolution in exams (Fig. 11a, b, choice A).

Similarities and differences concerning students' views about ID were as pronounced and notable in the "within" as in the "between" institutional comparisons (above): $49 \%$ of 
RWU or $23 \%$ of PC responders (means biology majors + nonmajors) had no opinion about ID (Fig. 8a, b, choice A). However, $16 \%$ of RWU or $27 \%$ of PC responders (mean biology majors + nonmajors) thought ID is a religious doctrine consistent with creationism (Fig. 8a, b, choice B), a view supported by $16 \%$ of RWU or $35 \%$ of PC biology majors (mean freshman + sophomore + junior + senior; Fig. 8c, d, choice B). These responses suggest different levels of knowledge about and perception of ID within institutions, but not necessarily endorsement or rejection of it. The combined responses of students who perceived ID as both a scientific alternative to evolution of equal scientific validity among scientists and a scientific theory about the origin and evolution of life on Earth - which may imply endorsement of or sympathy for ID - were $25 \%$ of RWU or $33 \%$ of PC (mean biology majors + nonmajors; Fig. $8 \mathrm{a}, \mathrm{b}$, choices C $+\mathrm{D}$ ); $23 \%$ of RWU or $27 \%$ of PC biology majors agreed with this view (mean freshman + sophomore + junior + senior; Fig. $8 \mathrm{c}$, d, choices $\mathrm{C}+\mathrm{D}$ ). Only $11 \%$ of RWU or $17 \%$ of PC responders (mean biology majors + nonmajors) rejected ID for considering it not scientific but proposed to counter evolution based on false scientific claims (Fig. 8a, b, choice E), an opinion shared by $16 \%$ of RWU or $22 \%$ of PC biology majors (mean freshman + sophomore + junior + senior; Fig. $8 \mathrm{c}$, d, choice E).

A small proportion of the students objected to evolutionary theory: $3 \%$ of RWU biology majors or $6 \%$ RWU nonmajors indicated that they feel uncomfortable hearing about evolution because it is in conflict with their faith (Fig. 9a, choice D); $<3 \%$ of PC students agreed with this view (data not shown); $10 \%$ of RWU or $6 \%$ of PC responders (mean biology majors + nonmajors) preferred science courses where plant and animal evolution is discussed but not human evolution (Fig. 10a, b, choice B); and $7 \%$ of RWU responders (mean biology majors + nonmajors) preferred not to answer questions concerning evolution in science exams (Fig. 11a, choice D); $<1 \%$ of PC students agreed with this view (data not shown).

\section{Relevance of This Study}

These results may represent a general tendency among secular or religious liberal arts private colleges in Northeastern USA, particularly those similar to RWU or PC (middle/upper-middle income population); more than $90 \%$ of the students at both institutions are native to New England (77\% at RWU versus $67 \%$ at PC) and the East Coast of the USA $(18 \%$ at RWU versus $25 \%$ at PC; Table 1). Because public support of science correlates positively to level of schooling and income (The Pew Research Center for the People and the Press 2005; National Science Foundation 2006), local and regional differential acceptance of evolution should be expected if similar assessments were conducted at public or other private secular/religious institutions. Note that acceptance of evolution in Northeastern USA (59\%) is the highest nationwide (The Pew Research Center for the People and the Press 2005).

Objections to teaching evolution in the science class might come from misinformed adults, rather than college students (Paz-y-Miño C. and Espinosa 2009). In fact, acceptance of the theory of evolution in the USA increases with level of education, from $20 \%$ in high school to $52 \%$ and $65 \%$ among college graduates or postgraduates, respectively (Brumfield 2005); our interinstitutional (64\% of biology majors, mean RWU + PC, Fig. 1a, choice A; $66 \%$ of biology majors, mean RWU + PC, Fig. 6 a, choices $\mathrm{A}+\mathrm{C})$ or intrainstitutional comparisons' results $(60 \%$ of RWU or $68 \%$ of PC biology majors, Fig. 7 a, choice A; $66 \%$ of both RWU and PC biology majors, Fig. 12a, b, choices $\mathrm{A}+\mathrm{C}$ ) are comparable to or higher than the latter. Adults who, for example, believe that humans were designed in the present form within the last 10,000 years coincide with the views of the least educated population (13-17-year-old adolescents; Brumfield 2005).

Numerous documents illustrate this further and help us understand the transition of the evolution/creationism controversy from high school to college. Because parents and community leaders influence high school policies (e.g., chronologically: Epperson v. Arkansas 1968; McLean vs. Arkansas Board of Education 1982; Edwards v. Aguillard 1987; Ohio State's Science Standards 2002, 2006; Kansas Science Standards 2005, 2007; Selman et al. vs. Cobb County Board of Education 2005, 2006; Kitzmiller et al. versus Dover Area School District, et al. 2005; Louisiana Academic Freedom 2008), teachers avoid conflicts with them by weakening the science curriculum. To comply with parents' demands and students' curiosity for catchy jargon, such as "intelligent design," $43 \%$ of high school teachers are willing to dedicate "equal time" to science and ID (National Science Foundation 2006), and 30\% and 31\% admit to have omitted evolution from their lessons or included nonscientific substitutes to evolution in their classes due to pressure, respectively (US National Science Teachers Association 2005). As a result, students arrive at college with weak science backgrounds; our data on nonmajors' acceptance of evolution for both interinstitutional $(46 \%$ mean RWU + PC, Fig. 6 b, choices A + C) and intrainstitutional comparisons ( $41 \%$ of RWU or $51 \%$ of PC means, Fig. 12a, b, choices A + C) demonstrate that.

Although the majority of RWU and PC biology majors seem receptive to learning evolution, a possible trend at sister institutions in Northeastern USA, it is crucial to continue assessing their perception and tendency to accept scientific principles, particularly now that objections to evolution resurface in the North American and European education 
systems (Miller et al. 2006; Cornish-Bowden and Cárdenas 2007), which nourish each other and influence the world's. The major implication of our findings, for the purpose of curricular/pedagogical reform, is that evolution - the course, the core theme of all sciences, the centerpiece of all naturalistic explanations about the cosmos-should be required at and integrated into all educational levels. Evolutionary theory should be offered widely and taught without distinction between biology majors and nonmajors as part of their science literacy. Our study demonstrates that students are enthusiastic about learning factual explanations about the origin and diversification of life, including humans, and that contact with biology courses determines their acceptance of evolutionary theory.

Higher-education and outreach programs in biology for school teachers are fundamental to integrate evolution into our society's culture. Biology school teachers in the USA rely on poor to excellent evolution state education standards that guide their teaching practices (sample 15 states, analysis by Moore 2002, based on data by Lerner 2000; see Lerner 2006 for newer statistics). However, instructors' personal views of evolution seem to influence the quality of schooling more than states' guidelines: $14-69 \%$ of school teachers question or reject evolution and even teach supernatural causation in science classes (Moore 2002). Only $28 \%$ of high school biology teachers acknowledge that humans have developed over millions of years with no deity involvement, but $47 \%$ believe that a supernatural being guided this process, and $16 \%$ assert that humans were created within the last 10,000 years (Berkman et al. 2008). Notably, high school biology teachers' acceptance of evolution also increases with conceptual understanding of evolutionary theory attained during their own college or graduate school training (concept map studies, Rutledge and Mitchell 2002; but see Nehm and Schonfeld 2007). Public (=former students of school teachers) support for teaching evolution increases too with scientific literacy, from $36 \%$ (lower science literacy) to $78 \%$ (higher science literacy; sample from American likely voters; Coalition of Scientific Societies 2008).

Three interacting factors seem to determine an individual's acceptance of evolution (Bishop and Anderson 1999; Downie and Barron 2000; Trani 2004): understanding the essence of science (=method to explore reality), familiarity with the processes and forces of change in organisms (mutations, gene flow, genetic drift, natural selection), and personal religious convictions. Thus, scientific literacy should suffice to generate public support of naturalistic rationalism (but see Pigliucci 2007), collective acceptance of science and technology to improve the quality of life (e.g., medicine needs evolution, Nesse et al. 2006), and appreciation for the evolutionary implications of empirical discoveries (e.g., unity of life deduced from DNA or chemical analyses; Lecointre and Le Guyader 2007). Various strategies have been suggested to promote such literacy in our society (Nelson 2007; Pigliucci 2007); here are those practiced by us (Paz-y-Miño C. and Espinosa 2009): discuss human evolution as scientific fact and address taxonomy retrospectively, from present (concestor/ alive taxa, i.e., chimpanzee and bonobo in respect to human) to past (ancestral/extinct forms, i.e., Australopithecus spp. in respect to Homo spp.; Gould 2002; Dawkins 2004); teach hominid evolution from the molecular and morphological perspectives (Lewin and Foley 2004; McKee et al. 2005; Stringer and Andrews 2005) and provide convincing examples of evolution in the human genome that place Homo within the apes and other primates, e.g., mosaic structure of genetic variation and genetic distances between modern humans and extinct Neanderthals in respect to other living apes (chimpanzee/bonobo, gorilla, orangutan; Pääbo 2003; Enard and Pääbo 2004; Green et al. 2006), origin of chromosome 2 by fusion of two ancestral chromosomes after the split of the human and chimpanzee/bonobo lineages, or diversification of the beta cluster of hemoglobin genes in Old and New World primates (see illustrations in Fairbanks 2007, and references therein); illustrate the correlation between geographic distribution of human genetic polymorphisms, blood types, and spoken-language evolution (Cavalli-Sforza 2000; Cavalli-Sforza and Feldman 2003; Atkinson et al. 2008); reveal the pattern of nervous systems' diversity across taxa by comparing/contrasting the human brain/mind with the neurobiology/cognition of animals (Wasserman and Zentall 2006) and highlight the evolutionary increase in brain volume/mental capacities within Homo, from $552 \mathrm{~cm}^{3}$ in Homo habilis (1.6-2.3 Myr ago) to $1,355 \mathrm{~cm}^{3}$ in Homo sapiens (0-0.2 Myr ago; Carroll 2003); remark on the molecular unity of life and link humans to all organisms by using phylogenetic analyses based on DNA/RNA (Cavalier-Smith 2006; Lecointre and Le Guyader 2007); emphasize that microevolution (change in the genetic makeup of populations) and macroevolution (speciation and the development of major processes and patterns in nature) are interdependent and that one cannot occur without the other (Mayr 2001); discuss novel examples of microevolution (tuberculosis resistance to antibiotics, Ernst et al. 2007, mutation rate associated with drug resistance in malaria pathogens, Mittra et al. 2006), and macroevolution (malaria host switching and Plasmodium diversification, Martisen et al. 2008; beak evolution in Darwin's finches, Grant and Grant 2006) currently at work; address misconceptions about "irreducible complexity" in nature (=key idea proposed by ID advocates to counter phyletic gradualism; Behe 1996, 2002, 2007) by dissecting the molecular and physiological concestry/ancestry of the bacterial flagellum (DeRosier 1998; McNab 1999; CavalierSmith 2006; Liu and Ochman 2007) or the structural 
configuration of the vertebrate eye (Lamb et al. 2007; Young 2008); and leave audiences with the idea that evolution is a gradual process by which the universe changes and that it includes the origin of life, its diversification, and the synergistic phenomena resulting from the interaction between life and the environment. Evolution is the language of the cosmos.

Acknowledgments We thank the departments of Biology at RWU and PC, and their students, faculty, and administrators for contributing to this study. Nicanor Austriaco and the BioSociety supported this initiative at PC. Patricia Kennedy, Patricia Pimental, and Julie Coccia facilitated logistics. Gregory Rogers, Kristen Procopio, and Julie Coccia provided the data to build Table 1. The Human Subject Review Boards at RWU and PC approved the protocols. Two reviewers provided comments that helped us improve the manuscript.

\section{References}

Atkinson QD, Meade A, Venditti C, Greenhill SJ, Pager M. Punctuational and gradual evolution in language trees. Science. 2008; 319:588.

Behe MJ. Darwin's blackbox. New York: Free Press; 1996.

Behe MJ. The challenge of irreducible complexity. Nat Hist. 2002; 111:74.

Behe MJ. The edge of evolution. New York: Free Press; 2007.

Berkman MB, Sandell-Pacheco H, Plutzer E. Evolution and creationism in America's classrooms: a national portrait. PLoS Biology. 2008; 6:920-4.

Bishop BA, Anderson CW. Student conceptions of natural selection and its role in evolution. J Res Sci Teach. 1999;27:415-27.

Brumfield G. Who has designs on your students' minds? Nature. 2005;434:1062-5.

Carroll SB. Genetics and the making of Homo sapiens. Nature. 2003;422:849-57.

Cavalier-Smith T. Cell evolution and Earth history: stasis and revolution. Phil Trans Royal Soc B. 2006;361:969-1006.

Cavalli-Sforza LL. Genes, peoples, and languages. New York: North Point; 2000.

Cavalli-Sforza LL, Feldman MW. The application of molecular genetic approaches to the study of human evolution. Nat Genet Suppl. 2003;33:266-75.

Coalition of Scientific Societies. Evolution and its discontents: a role for scientists in science education. FASEB J. 2008;22:1-4.

Cornish-Bowden A, Cárdenas ML. The threat from creationism to the rational teaching of biology. Biol Res. 2007;40:113-22.

Dawkins R. The ancestor's tale. Boston: Houghton Mifflin; 2004.

DeRosier DJ. The turn of the screw: the bacterial flagellar motor. Cell. 1998;93:17-20.

Donnelly LA, Boone WJ. Biology teacher's attitudes toward and use of Indiana's evolution standards. J Res Sci Teach. 2007;44:23657.

Downie JR, Barron NJ. Evolution and religion: attitudes of Scottish first year biology and medical students to the teaching of evolutionary biology. J Biol Educ. 2000;34:140-6.

Edwards v. Aguillard, 482 US 578. http://caselaw.lp.findlaw.com/ scripts/getcase.pl?navby $=$ CASE \&court $=$ US \&vol $=482 \&$ page $=578$; 1987.

Enard W, Pääbo S. Comparative primate genomics. Annu Rev Genomics Hum Genet. 2004;5:351-78.
Epperson v. Arkansas, 393 US 97. http://caselaw.lp.findlaw.com/ scripts/getcase.pl?court=US\&vol=393\&invol=97; 1968.

Ernst JD, Trevejo-Nuñez G, Banaiee N. Genomics and the evolution, pathogenesis, and diagnosis of tuberculosis. J Clin Invest. 2007; 117:1738-45.

Fairbanks DJ. Relics of Eden: the powerful evidence of evolution in human DNA. Amherst: Prometheus; 2007.

Forrest B, Gross RP. Creationism's Trojan horse: the wedge of intelligent design. New York: Oxford University Press; 2004.

Forrest BC, Gross RP. Biochemistry by design. Trends Biochem Sci. 2007;32:301-10.

Gould SJ. The structure of evolutionary theory. Cambridge: The Belknap Press of Harvard University; 2002.

Grant PR, Grant BR. Evolution of character displacement in Darwin's finches. Science. 2006;313:224-6.

Green RE, Krause J, Ptak SE, Briggs AW, Ronan MT, Simons JF, et al. Analysis of one million base pairs of Neanderthal DNA. Nature. 2006;444:330-6.

Hokayem H, BouJaoude S. College students' perceptions of the theory of evolution. J Res Sci Teach. 2008;45:395-419.

Kansas Science Standards. Summary of Key Changes to Kansas Science Standards adopted by the Kansas State Board of Education on November 8, 2005. http://www.kansasscience2005. com/Draft_2_Changes_added_by_board_as_of 8905.pdf; 2005.

Kansas Science Standards. Replacement with evolution-based standards on February 13, 2007. http://www.ksde.org/Default.aspx? tabid=144; 2007.

Kitzmiller et al. versus Dover Area School District et al. http://msnbcmedia. msn.com/i/msnbc/sections/news/051220 kitzmiller 342.pdf; 2005.

Lamb D, Collin SP, Pugh EN. Evolution of the vertebrate eye: opsins, photoreceptors, retina and eye cup. Nat Rev Neurosci. 2007;8: 960-75.

Lecointre G, Le Guyader H. The tree of life, a phylogenetic classification. Cambridge: Belknap; 2007.

Lerner LS. Good science, bad science: teaching evolution in the States. Washington DC: Thomas B. Fordham Foundation; 2000.

Lerner LS. Good, bad, and lots of indifferent: the state of State K-12 science standards and the fate of US science education. Freethought Today, 23, Freedom From Religion Foundation Inc. http://ffrf.org/fttoday/2006/janfeb/lerner.php; 2006.

Lewin R, Foley RA. Principles of human evolution. Malden: Blackwell; 2004.

Liu R, Ochman H. Stepwise formation of the bacterial flagellar system. Proc Natl Acad Sci. 2007;104:7116-21.

Louisiana Academic Freedom Act 2008 Senate Bill No. 561 signed by Governor Bobby Jindal into law on July 1, 2008. http:// www.legis.state.la.us/billdata/streamdocument.asp?did=472973; 2008.

Martisen ES, Perkins SL, Schall JJ. A three-genome phylogeny of malaria parasites (Plasmodium and closely related genera): evolution of life-history traits and host switches. Mol Phylogenet Evol. 2008;47:261-73.

Mayr E. What evolution is. New York: Basic Books; 2001.

McKee JK, Poirier FE, McGraw WS. Understanding human evolution. Upper Saddle River: Pearson Prentice Hall; 2005.

McLean v. Arkansas Board of Education, 529 F. Supp. 1255, (E.D. Ark. 1982). http://www.talkorigins.org/faqs/mclean-v-arkansas.html; 1982.

McNab RM. The bacterial flagellum: reversible rotary propellor and type III export apparatus. J Bacteriol. 1999;181:7149-53.

Miller KR. Falling over the edge. Nature. 2007;447:1055-6.

Miller KR. Only a theory: evolution and the battle for America's soul. New York: Viking Penguin; 2008.

Miller JD, Scott EC, Okamoto S. Public acceptance of evolution. Science. 2006;313:765-6. 
Mittra P, Vinayak S, Chandawat H, Das MK, Singh N, Biswas S, et al. Progressive increase in point mutations associated with chloroquine resistance in Plasmodium falciparum isolates from India. J Infect Dis. 2006;193:1304-12.

Moore R. Teaching evolution: do state standards matter? Bioscience. 2002;52:378-81.

Moore R. What are students taught about evolution? McGill J Educ. 2007;42:177-87.

Moore R, Kraemer K. The teaching of evolution \& creationism in Minnesota. Am Biol Teach. 2005;67:457-66.

National Science Foundation. Science and technology: public attitudes and understanding. In: Science and engineering indicators, Chapter 7; 2006. p. 7.1-7.46.

Nehm RH, Schonfeld IS. Does increasing biology teacher knowledge of evolution and the nature of science lead to greater preference for the teaching of evolution in schools? J Sci Teacher Educ. 2007;18:699-723.

Nelson CE. Teaching evolution effectively: a central dilemma and alternative strategies. McGill J Educ. 2007;42:265-83.

Nesse RM, Stearns SC, Omenn GS. Medicine needs evolution. Science. 2006;311:1071.

Ohio State's Science Standards: Critical analysis of evolution. http:// www.aproundtable.org/resources/Analysis_Evolution.pdf; 2002.

Ohio State's Science Standards. Ohio State Board of Education deletion of Creationist Lesson Plan from Model Curriculum and Critical Analysis Indicator from Science Standards. http://www. ohioscience.org/LessonPlanDeleted.shtml\#Continue, http://www. ohioscience.org/BOE Debate 2-14-06.pdf; 2006.

Pääbo S. The mosaic that is our genome. Nature. 2003;421:409-12.

Padian K, Matzke N. Darwin, Dover, 'intelligent design' and textbooks. Biochem J. 2009;417:29-42.

Paz-y-Miño CG, Espinosa A. Assessment of biology majors versus non-majors views on evolution, creationism and intelligent design. Evo Edu Outreach. 2009;2:75-83.

Petto AJ, Godfrey LR, editors. Scientists confront intelligent design and creationism. New York: Norton; 2007.

Pigliucci M. The evolution-creation wars: why teaching more science just is not enough. McGill J Educ. 2007;42:285-306.
Roger Williams University. Fact book 2007-2008. Office of Institutional Research; 2007. p. 5-13.

Rutledge ML, Mitchell MA. High school biology teachers' knowledge structure, acceptance \& teaching of evolution. Am Biol Teach. 2002;64:21-8.

Selman et al. vs. Cobb County Board of Education, Georgia Civil Action Case No. 1 02-CV-2325-CC: Decision of the Court Striking Down the Cobb County Evolution Disclaimer http://alt.cimedia.com/ajc/ pdf/evolution.pdf; 2005.

Selman et al. vs. Cobb County Board of Education, Georgia Civil Action Case No. 1 02-CV-2325-CC: Appeal by Cobb County. http://www. ca11.uscourts.gov/opinions/ops/200510341.pdf; 2006.

Sieger S, Castellan NJ. Nonparametric statistics for the behavioral sciences. Boston: McGraw Hill; 1988.

Stringer C, Andrews P. The complete world of human evolution. London: Thames \& Hudson; 2005.

The Gallup Poll. Evolution, creationism, intelligent design. http:// www.galluppoll.com/content/?ci=21814\&pg=1; 2007.

The Pew Research Center for the People and the Press. Public divided on origins of life: religion a strengths and weakness for both parties. Washington DC. http://people-press.org/report/254/religion-a-strength-and-weakness-for-both-parties; 2005.

Trani R. I won't teach evolution; it's against my religion. And now for the rest of the story.... Am Biol Teach. 2004;66: 419-27.

US National Science Teachers Association. Survey indicates science teachers feel pressure to teach nonscientific alternatives to evolution. http://science.nsta.org/nstaexpress/nstaexpress 20050328 pressrelease.htm; 2005.

Wasserman EA, Zentall TR. Comparative cognition: experimental explorations of animal intelligence. New York: Oxford University Press; 2006.

Young GC. Number and arrangement of extraocular muscles in primitive gnathostomes: evidence from extinct placoderm fishes. Biol Lett. 2008;4:110-4.

Young M, Taner E, editors. Why intelligent design fails: a scientific critique of the new creationism. New Brunswick: Rutgers University Press; 2004. 